Boise State University

ScholarWorks

Holocene Fire Occurrence and Alluvial Responses at the Leading Edge of Pinyon-Juniper Migration in the Northern Great Basin, USA

\author{
Kerrie N. Weppner \\ Boise State University \\ Jennifer L. Pierce \\ Boise State University \\ Julio L. Betancourt \\ U.S. Geological Survey
}

NOTICE: this is the author's version of a work that was accepted for publication in Quaternary Research. Changes resulting from the publishing process, such as peer review, editing, corrections, structural formatting, and other quality control mechanisms may not be reflected in this document. Changes may have been made to this work since it was submitted for publication. A definitive version was subsequently published in Quaternary Research, Volume 80, Issue 2, (2013). DOI: 10.1016/j.yqres.2013.06.004. 


\title{
Holocene fire occurrence and alluvial responses at the leading edge of pinyon-juniper migration in the Northern Great Basin, USA
}

\author{
Q13 Kerrie N. Weppner ${ }^{a, *}$, Jennifer L. Pierce ${ }^{a, *}$, Julio L. Betancourt ${ }^{b}$ \\ a Department of Geosciences, Boise State University, 1910 University Drive, Boise, ID 83725-1535, USA \\ ${ }^{\mathrm{b}}$ U.S. Geological Survey, 12201 Sunrise Valley Dr, Reston, VA 20192, USA
}

\section{A R T I C L E I N F O}

Article history:

Received 16 October 2012

Available online $\mathrm{xxxx}$

\section{Keywords:}

Fire

Holocene

Vegetation change

Charcoal

Debris flow

PJ woodlands

Albion Mountains

Idaho

Woodrat midden

\begin{abstract}
A B S T R A C T
Fire and vegetation records at the City of Rocks National Reserve (CIRO), south-central Idaho, display the inter- 24 action of changing climate, fire and vegetation along the migrating front of single-leaf pinyon (Pinus monophylla) 25 and Utah juniper (Juniperus osteosperma). Radiocarbon dating of alluvial charcoal reconstructed local fire occur- 26 rence and geomorphic response, and fossil woodrat (Neotoma) middens revealed pinyon and juniper arrivals. 27 Fire peaks occurred $\sim 10,700-9500,7200-6700,2400-2000,850-700$, and $550-400 \mathrm{cal}$ yr BP, whereas 28 $\sim 9500-7200,6700-4700$ and $\sim 1500-1000$ cal yr BP are fire-free. Wetter climates and denser vegetation fueled 29 episodic fires and debris flows during the early and late Holocene, whereas drier climates and reduced vegetation 30 caused frequent sheetflooding during the mid-Holocene. Increased fires during the wetter and more variable late 31 Holocene suggest variable climate and adequate fuels augment fires at CIRO. Utah juniper and single-leaf pinyon 32 colonized CIRO by 3800 and 2800 cal yr BP, respectively, though pinyon did not expand broadly until 33 $\sim 700$ cal yr BP. Increased fire-related deposition coincided with regional droughts and pinyon infilling $\sim 850-34$ 700 and 550-400 cal yr BP. Early and late Holocene vegetation change probably played a major role in acceler- 35 ated fire activity, which may be sustained into the future due to pinyon-juniper densification and cheatgrass 36 invasion.
\end{abstract}

(c) 2013 Published by Elsevier Inc. on behalf of University of Washington. 38

\section{Introduction}

In western North America, ongoing and future climate and landuse change could trigger widespread and possibly abrupt shifts in dominant vegetation, wildfire regimes, and post-fire erosion. These shifts will in turn impact fire and flood risks, conservation efforts, forest products, water resources, and other ecological goods and services. Our ability to anticipate and adapt to these changes will depend on how well we understand the effects of climatic change on vegetation, fire, and geomorphic response, and how these factors interact at different spatial and temporal scales (Allen, 2007).

Fire regimes are characterized by fuel consumption and fire spread patterns, fire size, and the distribution, frequency, intensity and severity of fire (Keeley et al., 2009). Climate ultimately governs vegetation and fire regimes, and vegetation-driven changes in fuel availability and continuity are primarily responsible for extent and severity of wildfires. Over annual to decadal time scales, climate variability controls the availability and moisture content of vegetation as fuel, and affects the frequency and regional synchroneity of wildfires (Heyerdahl et al., 2002; Westerling et al., 2006; Littell et al., 2009). Over decadal to millennial time scales, climate modulates the

\footnotetext{
* Corresponding authors. Fax: +12084264061.

E-mail addresses: kerrieweppner@u.boisestate.edu (K.N. Weppner), jenpierce@boisestate.edu (J.L. Pierce).
}

composition and structure of plant populations, and the nature of 63 the fire regime, including patterns of fire frequency, intensity, and 64 spread (Grissino-Mayer and Swetnam, 2000; Mensing et al., 2006). 65 Through strong positive feedbacks, changing fire regimes can also im- 66 pact vegetation and fuels. Despite the primary control of climate on 67 both fire regimes and vegetation, the causal links, temporal sequenc- 68 ing, and lags among climatic change, vegetation, and fire are complex. 69

An important objective for multiproxy paleoecological studies is to 70 sort out what circumstances determine the order and lags of re- 71 constructed changes in vegetation and fire both locally and regionally 72 (Clark et al., 1996; Veblen et al., 2003; Unbanhowar, 2004). More sim- 73 ply, which comes first, the change in vegetation or the shift in fire 74 regime? Directional changes in fire regimes coeval with changing vege- 75 tation across the region would implicate a greater role for vegetation 76 change (composition and structure). Synchronies in shifting fire re- 77 gimes across different vegetation types, some stable and others not, 78 $\begin{array}{ll}\text { would suggest a more direct influence of climate on fire regimes. } & 79\end{array}$

A related issue is how climate and vegetation interact to modify 80 the mechanisms and magnitude of fire-related erosion and sedimen- 81 tation. Unfortunately, few studies have the appropriate temporal and 82 spatial resolution to relate changes in vegetation, fire, and geomorphic 83 response throughout the Holocene. Wildfires are known to trigger 84 and accelerate hillslope erosion (e.g., Cannon et al., 2001a,b, Meyer 85 et al., 2001; Cannon et al., 2010) and the type of geomorphic response 86 (e.g., sheetfloods vs. debris flows) can be related to fire severity 87 
(Meyer et al., 2001; Pierce et al., 2004). Although post-fire geomorphic responses ultimately hinge on the occurrence, duration and intensity of rainfall in the window of time between fire and recovery of vegetation (Cannon et al., 2001a,b), the nature of fire-related erosion is controlled by several factors that include basin topography (Cannon et al., 2001a, b, 2010), vegetation type and structure (e.g., Wilcox et al., 2011), and fire size and severity (Meyer et al., 2001; Pierce et al., 2004; Cannon et al., 2010).

We use a novel approach of combining alluvial records of firerelated sedimentation with adjacent fossil woodrat (Neotoma) midden records of vegetation change in south-central Idaho. The City of Rocks National Reserve (CIRO) and adjacent Castle Rocks State Park encompass a maze of deeply weathered and towering granite outcrops separated by alluvial valleys. The numerous rock crevices and shelters preserve fossil woodrat middens and a record of plant migration, while the entrenched streams and arroyos expose fire-related deposits and charcoal in the alluvial stratigraphic sequences. The midden record is the focus of a separate paper (Betancourt, unpub. data), and the paleo-vegetation record is summarized here for comparison with the charcoal and alluvial stratigraphy.

$\mathrm{CIRO}$ is located along the late-Holocene migration front of Utah juniper [Juniperus osteosperma (Torr.) Little] and single-leaf pinyon (Pinus monophylla Torr. \& Frém.). Holocene shifts in temperature and precipitation/snowpack, and their annual phasing (seasonal timing), likely drove the northward migration of these two dominant conifers and associated changes in fire regime. The fortuitous preservation of fire and vegetation paleorecords within the same and adjacent drainage basins allows long-term analysis of fire, vegetation, and geomorphic change at CIRO.

\section{Study area}

CIRO is located on the southern slope of the Albion range on the Utah-Idaho border (Fig. 1). The study area spans an elevational range of $1600-2700 \mathrm{~m}$. Mean annual precipitation is $280 \mathrm{~mm}$, where most precipitation falls between April and June (Western Regional Climate Center).

Geologically, CIRO is comprised of the Almo granitic pluton (29 Ma) which intruded into the Elba quartzite (1.6 Ga) and Green Creek Complex $(2.5 \mathrm{Ga})$ of metasediments and granitic basement rock (Miller et al., 2008). Granite spires provide world-famous climbing opportunities, although most of CIRO is characterized by gentle to moderate slopes, with a mean slope of $15.6^{\circ}$. Mechanical and chemical weathering and erosion of Almo granite have blanketed CIRO in erodible granite grus (Pogue and Katz, 2008). Active arroyo cutting and fluvial incision reveal fire-related deposits in six headwater basins that drain into the Raft River, a tributary of the Snake River, Idaho (Table 1; Fig. 2). Livestock grazing and dry farming began at CIRO in 1888 (Morris, 2006), and this sparsely populated region is still primarily a ranching and agricultural community.

CIRO is a floristically diverse woodland-steppe ecotone, with over 450 documented plant species (John, 1995). Lower elevations $(<1800 \mathrm{~m})$ are dominated by big sagebrush (Artemisia tridentata Nutt.), antelope bitterbrush [Purshia tridentata (Pursh) DC] and an understory of native and non-native bunch grasses. Single-leaf pinyon dominates middle elevations (1600-2000 m) with Utah juniper and Rocky Mountain juniper (Juniperus scopulorum Sarg.). Patches of curl-leaf mountain mahogany (Cercocarpus ledifolious Nutt.) and aspen (Populus tremuloides Michx.) occupy middle to upper elevations (>1800 m). Limber pine (Pinus flexilis James) dominates the higher elevations $(>2000 \mathrm{~m}$ ). The reserve is dissected by riparian habitat that includes Rocky Mountain maple (Acer glabrum Torr.), box elder (Acer negundo L.), redosier dogwood (Cornus sericea L.) and narrow leaf cottonwood (Populus angustifolia James) (City Of Rocks National Reserve Vegetation Map).

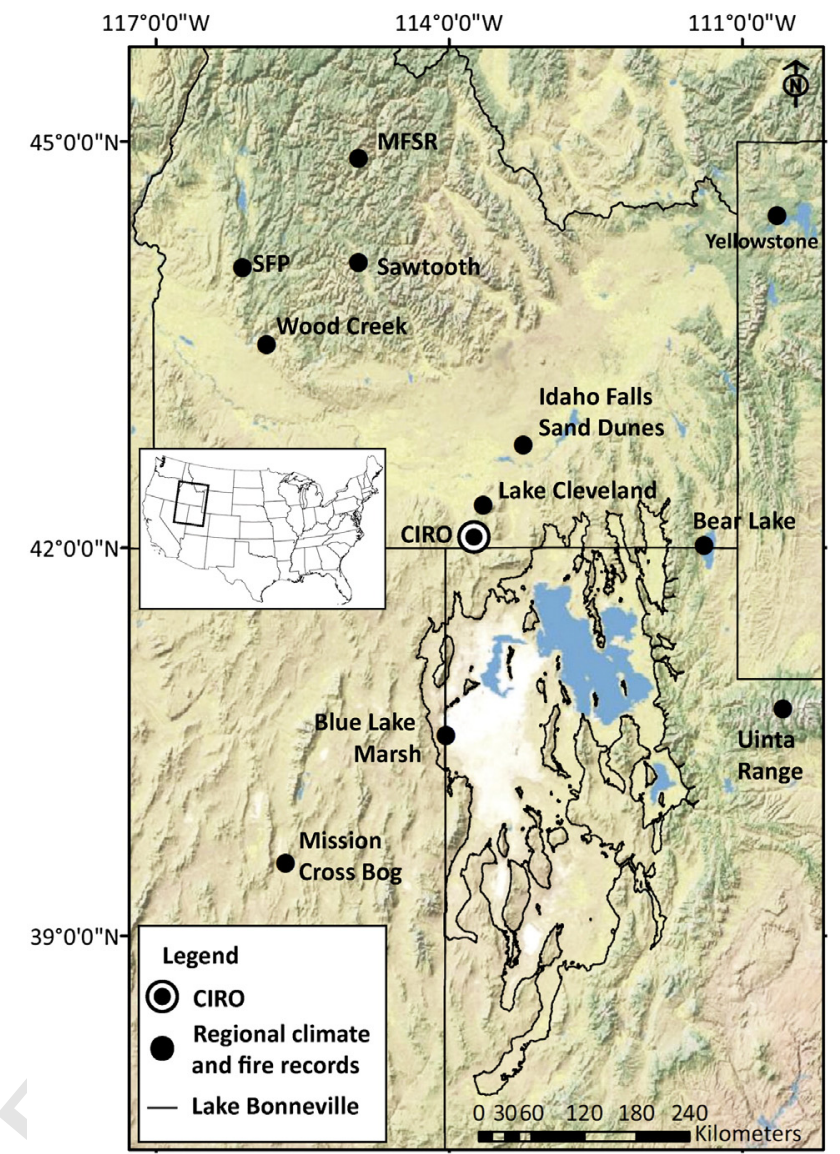

Figure 1. Map showing location of CIRO relative to sites of reconstructed paleoclimate and fire used for comparison in this study. Paleoclimate record sites include: the Bonneville Basin, UT (Murchison, 1989; Patrickson et al., 2010), Blue Lake Marsh, UT (Louderback and Rhode, 2009), Bear Lake, ID (Doner, 2009; Moser and Kimball, 2009), Uinta Range, UT (Gray et al., 2004; Corbett and Munroe, 2010), Lake Cleveland in the Albion Range, ID (Davis et al., 1986), Idaho Falls Sand Dunes, Snake River Plain, ID (Rittenour and Pearce 2011) and Mission Cross Bog, NV (Mensing et al., 2008). Reconstructed fire history sites include Yellowstone, WY (Meyer et al., 1995), Wood Creek, ID (Nelson and Pierce, 2010), the South Fork of the Payette River, ID (SFP; Pierce et al., 2004), the Middle Fork of the Salmon River, ID (MFSR; Riley, 2012), and the Sawtooth Range, ID (Svenson, 2010). The Lake Bonneville outline shows the approximate extent of the Bonneville highstand (20,000-16,000 yr BP; Automated Georeference Center, 2001).

\section{Methods}

We identified incised streams, incised alluvial fans and arroyos 152 using aerial photography in CIRO and nearby Castle Rocks State 153

Table 1

Summary of CIRO basin characteristics, number of alluvial charcoal and midden t1.2 sampling sites and number of fire radiocarbon ages per basin.

\begin{tabular}{|c|c|c|c|c|c|}
\hline $\begin{array}{l}\text { Basin } \\
\text { name }\end{array}$ & $\begin{array}{l}\text { Basin } \\
\text { area } \\
\left(\mathrm{km}^{2}\right)\end{array}$ & Lithology & $\begin{array}{l}\text { \# of alluvial } \\
\text { stratigraphy } \\
\text { sites }\end{array}$ & $\begin{array}{l}\text { \# of } \\
\text { midden } \\
\text { sites }\end{array}$ & $\begin{array}{l}\text { \# of }{ }^{14} \mathrm{C} \\
\text { (fire) } \\
\text { ages }\end{array}$ \\
\hline Almo Creek & 57.9 & $\begin{array}{l}\text { Quartzite to west, } \\
\text { gneiss to east }\end{array}$ & 2 & 0 & 3 \\
\hline Stines Creek & 6.9 & $\begin{array}{l}\text { Quartzite to west, } \\
\text { gneiss to south }\end{array}$ & 1 & 0 & 1 \\
\hline Graham Creek & 14 & $\begin{array}{l}\text { Quartzite to west, } \\
\text { granite to east, } \\
\text { gneiss to south }\end{array}$ & 1 & 0 & 1 \\
\hline Circle Creek & 17.4 & $\begin{array}{l}\text { All granite except } \\
\text { gneiss fin to east }\end{array}$ & 10 & 18 & 25 \\
\hline Heath Canyon & 13.9 & $\begin{array}{l}\text { Granite to north, } \\
\text { quartzite to south }\end{array}$ & 1 & 0 & 7 \\
\hline $\begin{array}{r}\text { Emigrant } \\
\text { Canyon }\end{array}$ & 13.3 & Quartzite & 0 & 2 & 0 \\
\hline
\end{tabular}




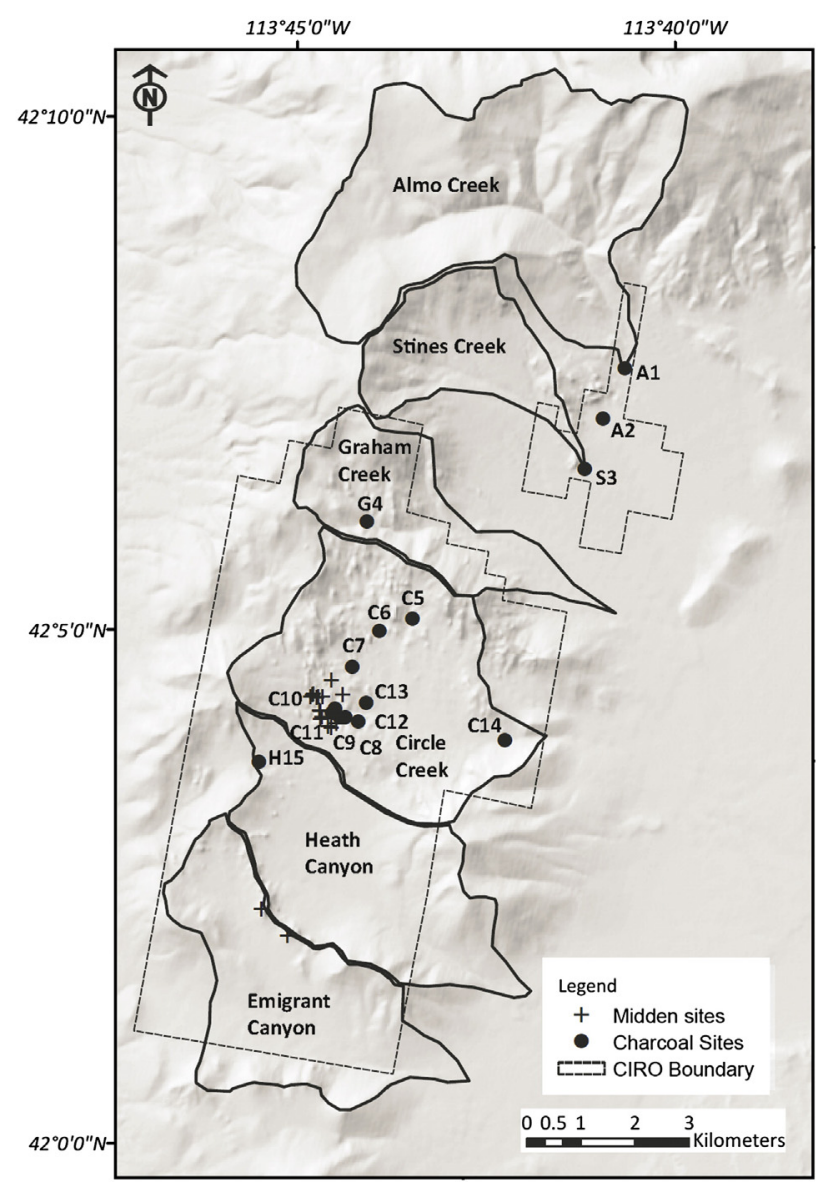

Figure 2. Map showing the CIRO study area, Castle Rocks State Park boundary (north) and the CIRO park boundary (south), six delineated drainage basins, charcoal sampling sites, and midden sampling sites. Subbasins within Circle Creek (C5-C14) are not shown, but include North Fork of Circle Creek, Center Circle Creek, South Fork of Circle Creek, as well as numerous unnamed small basins. The main fork of Circle Creek is established near site C14.

Park, which are both managed by the National Park Service office in Almo, Idaho. In the field, targeted exposures were cleaned with a shovel and thoroughly examined for alluvial charcoal. Exposures containing charcoal were sampled for radiocarbon dating and macrofossil analysis.
To create a spatially representative dataset of fire events, we dated 159 charcoal samples from many of the small drainages throughout the 160 study area. In exposures containing multiple fire-related deposits, 161 we dated charcoal fragments from multiple distinct units. At expo- 162 sures containing a few charcoal-rich deposits, we dated the upper- 163 most unit ( $>25 \mathrm{~cm}$ depth to avoid surface material that may have 164 experienced bioturbation) and the lowermost unit, so that we could 165 reconstruct a time frame of fire and deposition at the site. The number 166 of charcoal samples collected varied depending on fragment size and 167 abundance.

We used deposit characteristics (e.g., clast sorting, size, orienta- 169 tion, and matrix textures) to infer depositional processes (e.g., 170 sheetflood, debris flow, overbank flood, channel flood), and identified 171 soil properties according to Birkeland et al. (1991; Table 2). 172 Q6 Charcoal-rich deposits are termed "fire-related" and post-fire geo- 173 morphic response is inferred from deposit characteristics (e.g., 174 sheetfloods vs. debris flows). Variations in depositional process may 175 in turn reflect variations in fire-severity and size. Prior studies of 176 fire events preserved in alluvial records (Meyer et al., 1995; Pierce 177 et al., 2004), combined with modern studies of post-fire erosional re- 178 sponse (e.g., Cannon et al., 2001a), show that severely burned basins 179 are more likely to produce large debris flows than similar basins with 180 low burn severity, even during 1-2 year storm events. Conversely, 181 basins burned in patchy or lower severity fires produce erosional 182 events with lower proportions of sediment, such as sheetfloods or 183 floods (e.g., Pierce et al., 2004). While other factors such as storm se- 184 verity can also control the type of erosional response following fire, 185 for a given basin, variations in the types of fire-related deposit can 186 be used to infer possible changes in fire severity and extent within a 187 given basin.

We prioritized annually-produced wood (i.e. twigs, leaves, seeds) 189 for radiocarbon dating to decrease "inbuilt age," which is the differ- 190 ence between the age of wood formation and date of fire (Gavin, 191 2001). We selected angular wood fragments over rounded ones, 192 according to Folk (1965), to avoid dating re-worked charcoal 193 (e.g., Meyer et al., 1995). Charcoal macrofossils (defined as >1 mg) 194 were dated with Accelerator Mass Spectrometry (AMS) ${ }^{14} \mathrm{C}$. AMS 195 ${ }^{14} \mathrm{C}$ dates were calibrated into calendar years before 1950 AD. 196 (cal yr BP) using the CALIB 6.0.1 program (Stuiver and Reimer, 197 1993 ) and results are presented as the median of the $1 \sigma$ and $2 \sigma$ age 198 distributions (Table 3). Individually calibrated fire ages were summed 199 and presented as a cumulative probability distribution.

Given the resolution of radiocarbon dating and inbuilt age of the 201 charcoal, it is not possible to determine if charcoal samples with 202 overlapping $1 \sigma$ and $2 \sigma$ ages were produced from the same fire. 203

Table 2

Summary of deposit characteristics at CIRO.

\begin{tabular}{|c|c|c|c|c|c|c|}
\hline $\begin{array}{l}\text { Depositional } \\
\text { process }\end{array}$ & Deposit characteristics & Sorting & Texture & Clast size range & $\begin{array}{l}\text { Maximum } \\
\text { clast size }\end{array}$ & Deposit thickness \\
\hline $\begin{array}{c}\text { Sheetflood } \\
\text { deposit }\end{array}$ & $\begin{array}{l}\text { Clast-supported, form } \\
\text { alternating fine/coarse } \\
\text { grained couplets }\end{array}$ & Moderately-well sorted & $\begin{array}{l}\text { Fine unit: loam, } \\
\text { sandy-loam, silty-loam, } \\
\text { coarse unit: sand, } \\
\text { loamy-sand, sandy-loam }\end{array}$ & $\begin{array}{l}\text { Fine unit: }<20 \% \text { coarser } \\
\text { than } 2 \mathrm{~mm} \text {, coarse unit: } \\
20-50 \% \text { coarser than } \\
2 \mathrm{~mm}\end{array}$ & $\begin{array}{l}\text { Fine unit: } 3 \mathrm{~mm} \text {, } \\
\text { Coarse unit: } 10 \mathrm{~mm}\end{array}$ & $\begin{array}{l}\text { Individual } \\
\text { couplets vary } \\
\text { between } 0.25 \\
\text { and } 6 \mathrm{~cm}\end{array}$ \\
\hline $\begin{array}{l}\text { Debris flow } \\
\text { deposit }\end{array}$ & $\begin{array}{l}\text { Matrix-supported, } \\
\text { randomly oriented } \\
\text { clasts floating in a } \\
\text { fine-grained matrix }\end{array}$ & Poorly-sorted & $\begin{array}{l}\text { Matrix: loam, silty-loam, } \\
\text { sometimes silty-clay-loam }\end{array}$ & $30 \%$ coarser than $2 \mathrm{~mm}$ & $\begin{array}{l}1-20 \mathrm{~cm} \text {, rarely } \\
\text { exceed } 20 \mathrm{~cm}\end{array}$ & $\begin{array}{l}\text { Vary in depth } \\
\text { but can reach } \\
100+\mathrm{cm}\end{array}$ \\
\hline
\end{tabular}

fine-grained matrix, form cohesive vertical and sometimes overhanging faces in stratigraphic profile

5-40\% coarser than $2 \mathrm{~mm}$ Finer than $10 \mathrm{~mm}$

5-50\% coarser than $2 \mathrm{~mm} \quad 30 \mathrm{~cm}$
Vary in depth but can reach $75 \mathrm{~cm}$ Vary in depth but can reach $75 \mathrm{~cm}$ 
Table 3

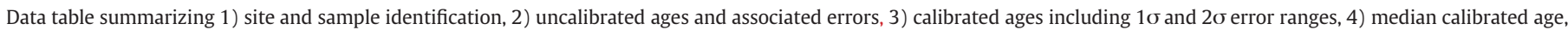

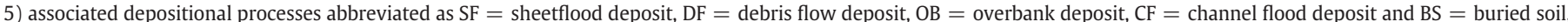

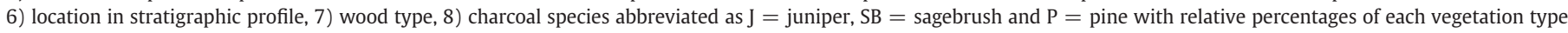
shown in parentheses and ordered respectively, 9) and charcoal abundance within the deposit.

\begin{tabular}{|c|c|c|c|c|c|c|c|c|c|c|c|c|}
\hline Site ID & Lab ID & Sample ID & $\begin{array}{l}{ }^{14} \mathrm{C} \\
\text { age BP }\end{array}$ & $\begin{array}{l}\text { Analytical } \\
\text { error } \pm\end{array}$ & $\begin{array}{l}\text { Calibrated age } \\
\text { (cal yr BP) }\end{array}$ & Error $(1 \sigma)$ & Error $(2 \sigma)$ & $\begin{array}{l}\text { Deposit } \\
\text { type }\end{array}$ & $\begin{array}{l}\text { Depth } \\
(\mathrm{cm})\end{array}$ & $\begin{array}{l}\text { Charcoal } \\
\text { type }\end{array}$ & $\begin{array}{l}\text { Burned vegetation-type } \\
(\%)(J)(S B)(P)\end{array}$ & $\begin{array}{l}\text { Charcoal } \\
\text { abundance }\end{array}$ \\
\hline \multicolumn{13}{|c|}{ Drainage Basin: Almo Creek } \\
\hline \multirow[t]{2}{*}{ A1 } & 80536 & KWCA02-2-3A & 485 & 20 & 520 & $512-527$ & $506-535$ & SF & 130 & Twig & (17) (67) (17) & Abundant \\
\hline & AA88400 & KWCA02-5 & 2428 & 39 & 2470 & $2370-2514$ & $2362-2582$ & SF & 185 & Wood & $(40)(40)(20)$ & Present \\
\hline A2 & 80537 & AHCA06B-3 & 900 & 20 & 810 & $767-839$ & $756-886$ & SF & 135 & Wood & $(0)(100)(0)$ & Scarce \\
\hline \multicolumn{13}{|c|}{ Drainage Basin: Stines Creek } \\
\hline S3 & 80538 & AHCA04 & 10,875 & 35 & 12,740 & $12,656-12,803$ & $12,626-12,887$ & $\mathrm{BS} / \mathrm{DF}$ & 105 & Wood & Not identified & Scarce \\
\hline \multicolumn{13}{|c|}{ Drainage Basin: Graham Creek } \\
\hline G4 & AA88389 & KWCR06-3 & 1655 & 37 & 1560 & $1521-1609$ & $1418-1468$ & $\mathrm{DF}$ & 90 & Twig & $(50)(7)(43)$ & Abundant \\
\hline \multicolumn{13}{|c|}{ Drainage Basin: Circle Creek, location: North Fork of Circle Creek } \\
\hline $\mathrm{C} 5$ & AA88388 & SPCR03-1 & 180 & 35 & 180 & $132-208$ & $103-300$ & DF & 50 & Wood & $(38)(25)(38)$ & Present \\
\hline \multirow[t]{3}{*}{ C6 } & AA88390 & NCCR01-1 & 415 & 35 & 490 & $485-495$ & $480-500$ & SF & 80 & Twig & $(40)(50)(10)$ & Present \\
\hline & AA88391 & NCCR01-4 & 356 & 35 & 400 & $377-428$ & $314-498$ & DF & 135 & Wood & $(28)(40)(32)$ & Abundant \\
\hline & AA88397 & NCCR04-5B & 846 & 42 & 760 & $708-790$ & $681-802$ & SF & 160 & Twig & (0) (89) (11) & Present \\
\hline \multicolumn{13}{|c|}{ Drainage Basin: Circle Creek, location: Middle Fork of Circle Creek } \\
\hline $\mathrm{C7}$ & AA88398 & KWCR15-1 & 913 & 36 & 830 & $781-880$ & $750-917$ & $\mathrm{OB}$ & 95 & Wood & (15) (69) (15) & Abundant \\
\hline \multicolumn{13}{|c|}{ Drainage Basin: Circle Creek, location: South Fork of Circle Creek } \\
\hline \multirow[t]{5}{*}{$\mathrm{C} 8$} & AA88396 & TRCR02-2B & 786 & 36 & 710 & $682-724$ & $671-752$ & $\mathrm{DF}$ & 75 & Wood & $(40)(60)(0)$ & Present \\
\hline & 80,524 & TRCR02-4A & 3990 & 20 & 4490 & $4483-4512$ & $4418-4450$ & SF & 160 & Branch & $(35)(35)(41)$ & Present \\
\hline & 80525 & TRCR05A-1 & 8605 & 25 & 9550 & $9535-9567$ & 9519-9588 & DF & 175 & Wood & not identified & Scarce \\
\hline & 80526 & TRCR05C-4 & 9155 & 25 & 10,290 & $10,250-10,319$ & $10,240-10,319$ & SF & 250 & Wood & $(67)(11)(22)$ & Abundant \\
\hline & 80527 & TRCR05B-5 & 9390 & 25 & 10,620 & $10,572-10,657$ & $10,549-10,702$ & SF & 300 & Wood & $(100)(0)(0)$ & Scarce \\
\hline \multirow[t]{2}{*}{ C9 } & AA88384 & KRCR01-1A & 308 & 35 & 390 & $358-430$ & $298-469$ & SF & 25 & Needle & (47) (27) (27) & Abundant \\
\hline & AA88385 & KRCR01-7B & 425 & 35 & 490 & $468-516$ & $430-531$ & SF & 150 & Pod & (7) (57) (36) & Abundant \\
\hline \multirow[t]{2}{*}{$\mathrm{C} 10$} & AA88387 & KWCR04-1 & 3393 & 41 & 3640 & $3607-3687$ & $3554-3725$ & SF & 50 & Twig & $(50)(50)$ & Scarce \\
\hline & AA88392 & KWCR11-1 & 9469 & 56 & 10,720 & $10,598-10,783$ & $10,553-10,869$ & OB & 230 & Wood & $(100)(0)(0)$ & Present \\
\hline \multirow[t]{2}{*}{ C11 } & 80534 & KWCR03-2-1A & 2250 & 20 & 2290 & $2288-2327$ & $2182-2331$ & DF & 75 & Wood & $(33)(0)(67)$ & Abundant \\
\hline & 80535 & KWCR03-2-2 & 2050 & 20 & 2020 & 1988-2019 & 1972-2033 & $\mathrm{CF}$ & 140 & Wood & not identified & Abundant \\
\hline \multirow[t]{6}{*}{$\mathrm{C} 12$} & 80518 & TRCRO4-1C & 375 & 20 & 450 & $334-349$ & $325-363$ & SF & 60 & Seed & $(32)(32)(37)$ & Abundant \\
\hline & 80519 & TRCRO4-2B & 660 & 20 & 610 & $567-584$ & $562-594$ & SF & 115 & Branch & (33) (67) (0) & Abundant \\
\hline & 80520 & TRCR04-3B & 770 & 20 & 690 & $676-699$ & $674-727$ & DF & 145 & Seed & $(23)(46)(31)$ & Abundant \\
\hline & 80521 & TRCR04-5 & 5995 & 20 & 6830 & 6792-6866 & 6761-6897 & DF & 250 & Wood & (0) (33) (67) & Present \\
\hline & 80522 & TRCR04-6A & 6090 & 20 & 6950 & 6928-6980 & 6894-7007 & DF & 335 & Wood & $(8)(46)(46)$ & Abundant \\
\hline & 80523 & TRCR04-7B & 6280 & 60 & 7210 & 7154-7290 & $7012-7330$ & SF & 380 & Wood & (0) (45) (55) & Abundant \\
\hline C13 & 80539 & AHCR19-3 & 175 & 20 & 184 & $150-189$ & $268-282$ & $\mathrm{DF}$ & 75 & Twig & $(40)(40)(20)$ & Abundant \\
\hline \multicolumn{13}{|c|}{ Drainage Basin: Circle Creek, location: Main Fork of Circle Creek } \\
\hline \multirow[t]{3}{*}{$\mathrm{C} 14$} & 80528 & CCCR01-2-1 & 4135 & 20 & 4680 & $4602-4684$ & $4580-4801$ & SF & 83 & Wood & $(0)(100)(0)$ & Scarce \\
\hline & AA88386 & CCCR01-2B & 5864 & 45 & 6680 & $6632-6733$ & $6549-6782$ & SF & 180 & Wood & $(0)(43)(57)$ & Present \\
\hline & 80529 & CCCR02-4 & 6165 & 20 & 7080 & $7017-7128$ & $6989-7167$ & $\mathrm{SF}$ & 230 & Wood & (0) (72) (28) & Abundant \\
\hline \multicolumn{13}{|c|}{ Drainage Basin: Heath Canyon } \\
\hline \multirow[t]{6}{*}{$\mathrm{H} 15$} & AA88394 & KWCR17-1 & 189 & 34 & 180 & $147-191$ & $136-225$ & SF & 30 & Twig & $(25)(0)(75)$ & Abundant \\
\hline & 80531 & KWCR18-2-2B & 2230 & 20 & 2240 & $2185-2243$ & 2169-2318 & $\mathrm{BS} / \mathrm{DF}$ & 290 & Wood & (0) (67) (33) & Abundant \\
\hline & 80532 & KWCR18-2-3B & 5905 & 20 & 6720 & 6714-6743 & 6670-6756 & DF & 350 & Pod & $(33)(0)(67)$ & Abundant \\
\hline & 80533 & KWCR18-2-3C & 6230 & 25 & 7170 & 7137-7214 & $7041-7227$ & DF & 420 & Wood & $(92)(0)(8)$ & Abundant \\
\hline & AA88393 & KWCR12-4B & 8862 & 59 & 9970 & $9882-10,148$ & $9728-10,148$ & $\mathrm{DF}$ & 500 & Wood & $(92)(0)(8)$ & Abundant \\
\hline & AA88395 & KWCR18-3 & 10,034 & 56 & 11,540 & $11,395-11,643$ & $11,278-11,770$ & $\mathrm{DF}$ & 560 & Twig & $(71)(12)(18)$ & Abundant \\
\hline
\end{tabular}

Separate sites containing charcoal with similar ages that were geographically distinct (i.e., found in separate tributaries) were assumed to represent periods of multi-basin fires, and large probability peaks were used to denote large, widespread fire events. Small and/or lower severity fires are inferred from fire-related sheetflood deposits, whereas large and/or higher severity fires are inferred from firerelated debris flow deposits (Meyer et al., 2001; Pierce et al., 2004).

We applied a stratigraphically-based model to correct the fire record for "taphonomic bias", which is the over-representation of younger macrofossils relative to older macrofossils due to destructive weathering and erosional processes observed in archeological and geologic records. Surovell et al. (2009) based this empirical model on terrestrial records of volcanic ash deposition where frequency distributions appear to diminish over time and on ice sheet records of volcanic deposition that are presumably not subjected to destructive 218 terrestrial processes because they do not exhibit characteristics of a 219 fading record. The correction is as follows:

$n_{t}=5.73 \times 10^{6}(t+2176.4)^{-1.39}$

where $n_{t}$ is the number of radiocarbon dates surviving from time $t .222$

Surovell et al. (2009) recommend application of the taphonomic 223 bias correction for samples older than $750 \mathrm{cal}$ yr BP because younger 224 samples are least likely to experience decomposition. We suggest that 225 the fading fire record at CIRO, however, is primarily a function of 226 depth of incision, where fire-related deposits deeper than natural expo- 227 sures are not exposed and therefore not sampled. All but one exposure 228 with ages $<5000 \mathrm{cal}$ yr BP (96\%) were sampled from 0-200 cm depth, 229 
while $77 \%$ of samples with ages $>5000$ cal yr BP are exposed between 200 and $600 \mathrm{~cm}$. One debris flow deposit containing sparse charcoal was dated 12,700 cal yr BP. Several fire-related deposits older than 9000 cal yr BP, however, contain abundant charcoal, suggesting that charcoal decomposition is not as important as stratigraphic exposure, or that charcoal preservation varies on a site-by-site basis (Table 3). Based on these age-depth relationships, taphonomic bias likely plays a secondary role in the CIRO record. Accordingly, the Surovell et al. (2009) correction was applied only to ages $>5000$ cal yr BP, when ages are under-represented due to lack of exposure.

We binned the radiocarbon-dated and stratigraphically-inferred ages of deposits (based on location within the profile, upper and lower age constraints, and depositional characteristics) into 500-year bins to identify Holocene trends in fire-related sedimentation, and separated debris flow deposits, sheetflood deposits and overbank deposits to examine changes in depositional process over time. We identified and classified charcoal macrofossils (10-200 mg) using a $20 \times$ power microscope as "pine", "juniper" or "sagebrush" based on wood characteristics (see Weppner, 2012) by comparison with magnified images and descriptions of burned wood (Adams and Murray, 2011). Based on first appearance in the woodrat midden record, we assumed that pine charcoal prior to 2800 cal yr BP belongs to limber pine, and after that date to either limber pine or single-leaf pinyon. We assumed that juniper charcoal before 3800 cal yr BP was Rocky Mountain juniper, whereas charcoal since then was Utah juniper or Rocky Mountain juniper.

Thirty fossil woodrat middens were collected, dated and analyzed, spanning the last 45,000 yr, using well-established methods detailed in Betancourt et al. (1990). Here we focus primarily on the occurrences of Utah juniper and single-leaf pinyon plant macrofossils, and the inferred colonization and expansion history of these two trees. In addition, we infer periods of high ecosystem productivity during the Holocene (i.e., times when woodrat populations flourished and midden construction increased) from relative abundances of radiocarbon ages in middens from CIRO, Oneida Narrows in southeastern Idaho and the Lost River Range in south-central Idaho (Webb and Betancourt, 1990; Smith and Betancourt, 2003). Midden ages were not corrected for taphonomic bias because middens are typically preserved in rock shelters and therefore less susceptible to erosion and weathering processes.

\section{Results}

The midden record indicates that Rocky Mountain juniper, limber pine and sagebrush have occupied CIRO since $\sim 45,000$ cal yr BP. Utah juniper colonized CIRO $\sim 3800$ cal yr BP and single-leaf pinyon $\sim 2800$ cal yr BP (Fig. 5a). Single-leaf pinyon is abundant in middens from $\sim 2800-2400$ cal yr BP, but absent in ones dated $\sim 2400$ $700 \mathrm{cal}$ yr BP. This suggests that either slow expansion or colonization occurred as two events, with the first event as a failed invasion and the second event successfully establishing single-leaf pinyon as the dominant species after 700 cal yr BP. (Fig. 5b). Summed probability distributions of midden radiocarbon ages from CIRO, Oneida Narrows, and the Lost River Range record a peak between 5000 and 1500 cal yr BP. No midden ages are recorded between $\sim 1500$ and 1100 cal yr BP, but increase again 700-300 cal yr BP (Fig. 5c; Smith and Betancourt, 2003).

Alluvial charcoal radiocarbon ages show five episodes of enhanced fire activity during the Holocene (Fig. 5d). The first episode $(\sim 10,700$ 9500 cal yr BP) records five fires in Circle Creek and Heath Canyon over a 1000 year period, the second fire episode $~ 7200-6700 \mathrm{cal}$ yr BP records seven fires in Circle Creek and Heath Canyon during a 500 year timeframe, and the third fire period ( 2400-2000 cal yr BP) records five fires in Circle Creek, Heath Canyon and Almo Creek during a $\sim 400$ year period. The two most recent fire episodes are the most geographically widespread (fires burned in all basins except Graham Creek) and occurred 850-700 and 550-400 cal yr BP recording 15 fires during $~ 450 \mathrm{yr}$. No fires were recorded between 9500-7200 and 293 6700-4700 cal yr BP (see Weppner, 2012 for more details).

Two stratigraphic profiles (C6 and C11) produced stratigraphically- 295 inverted radiocarbon ages from distinct deposits with clear boundaries. 296 Because $1 \sigma$ and $2 \sigma$ age errors do not overlap (Table 3), we infer that 297 older macrofossils were transported from an earlier fire. Although 298 these ages cannot date depositional process, they do represent timing 299 of past fires because all ages are from charcoal fragments.

Charcoal identification, where possible, showed mostly juniper 301 (79\%; cf. J. scopulorum) between 11,500 and 9900 cal yr BP, while 302 pine (cf. P. flexilis) and sagebrush account for $14 \%$ and 7\%, respectively. 303 Between 7200 and $6700 \mathrm{cal}$ yr BP, macrofossils consist of 20\% juniper 304 (cf. J. scopulorum), 40\% sagebrush and 40\% pine (cf. P. flexilis). At 305 4700-1500 yr BP, which includes the period during first colonization 306 of $J$. osteosperma and P. monophylla, was split roughly three ways 307 among juniper (cf. J. scopulorum/J. osteosperma), sagebrush, and pine 308 (P. flexilis/P. monophylla). Between 850-700 and 550-400 cal yr BP, 309 however, the majority of the charcoal samples were sagebrush (Fig. 5e). 310

Deeply-incised arroyos that contain abundant fire-related de- 311 posits are common in granitic and gneissic basins at CIRO (Table 1). 312 However, fire-related deposits are limited in deep arroyos formed in 313 quartzite basins (Table 1). This suggests that hillslopes formed in 314 more resistant quartzite are less susceptible to fire-related erosional 315 events. For example in 2000, a mixed-severity crown fire burned 316 $\sim 8.5 \mathrm{~km}^{2}$ in quartzite terrain of southern CIRO (Monitoring Trends 317 in Burn Severity, 2011). Local residents observed increased fire- 318 related surface erosion during a storm event a few days following 319 this fire (Morris, 2006), which probably was due to surface rilling 320 (Skakesby and Doerr, 2006). There was no field evidence, however 321 for large-scale, post-fire erosion, such as sheetflood or debris flow de- 322 position. The quartzite terrain, now characterized by standing dead 323 pinyon and juniper, has since been invaded by cheatgrass. By con- 324 trast, field observations in granitic and gneissic basins indicate active 325 arroyo cutting and regular sheetflood transport of sediments from 326 upstream channels and arroyos. During a two-week storm totaling 327 $2 \mathrm{~cm}$ of precipitation (July-August 2010; Western Regional Climate 328 Center), $30 \mathrm{~cm}$ of material was eroded from the base of arroyo C12, 329 fresh incision occurred at arroyos C8 and H15, and sheetfloods were 330 deposited elsewhere. Debris flows, however, are rare in the modern 331 record because no large fires have burned in granitic basins. In the 332 paleorecord, sheetflood deposits comprise $57 \%$ of total measured allu- 333 vial thickness, whereas debris flow deposits and overbank deposits 334 make up 37\% and 6\% of alluvial thickness, respectively (Fig. 5f). 335

Between 6500 and 2500 cal yr BP, only 4\% of alluvial thickness was 336 deposited, and debris flow deposition was minimal (Fig. 5f). Four thin 337 $(<10 \mathrm{~cm})$, muddy debris flow deposits containing fine-grained clasts 338 were identified during this time. These deposits are notably different 339 from the thick $(>40 \mathrm{~cm}$ ) debris flow deposits containing coarser clasts, 340 four of which were deposited before $9500 \mathrm{cal} \mathrm{yr} \mathrm{BP,} \mathrm{and} \mathrm{fourteen} \mathrm{were} 341$ deposited after 2400 cal yr BP. (Figs. 3 and 5f). Stratigraphic age gaps 342 were observed at $\mathrm{C} 12$ between $\sim 700$ and 7000 cal yr BP, which is sep- 343 arated by $100 \mathrm{~cm}$ of undated charcoal-poor sheetfloods, and at H15 be- 344 tween 2200 and 6800 cal yr BP (Fig. 3). Neither site, however, shows 345 stratigraphic evidence of erosion (e.g., cut-and-fill or unconformable 346 contacts between deposits), and dated units are laterally continuous 347 within exposures.

Although modern soils at CIRO are poorly developed, with absent to 349 weakly developed B-horizons (USDA et al., 2011), we observed four 350 Q7 well-developed Holocene soils (Weppner, 2012). At site S3, A and Bt 351 horizons developed on a 12,700 cal yr BP debris flow deposit that was 352 subsequently buried by sheetfloods and capped by an undated debris 353 flow deposit that also exhibits extensive soil development. At H15, A 354 and Bt horizons are developed on a $\sim 2230$ cal yr BP debris flow deposit 355 buried under $<300 \mathrm{cal}$ yr BP sheetflood deposits. Another soil containing 356 a Bt horizon was developed on a 2290 cal yr BP fire-related debris flow 357 deposit exposed in streambank site C10/C11. 
This is an author-produced, peer-reviewed version of this article. The final, definitive version of this document can be found online at Quaternary Research, published by Elsevier. Copyright restrictions may apply. DOI: 10.1016/j.yqres.2013.06.004.

K.N. Weppner et al. / Quaternary Research $x x x$ (2013) $x x x-x x x$

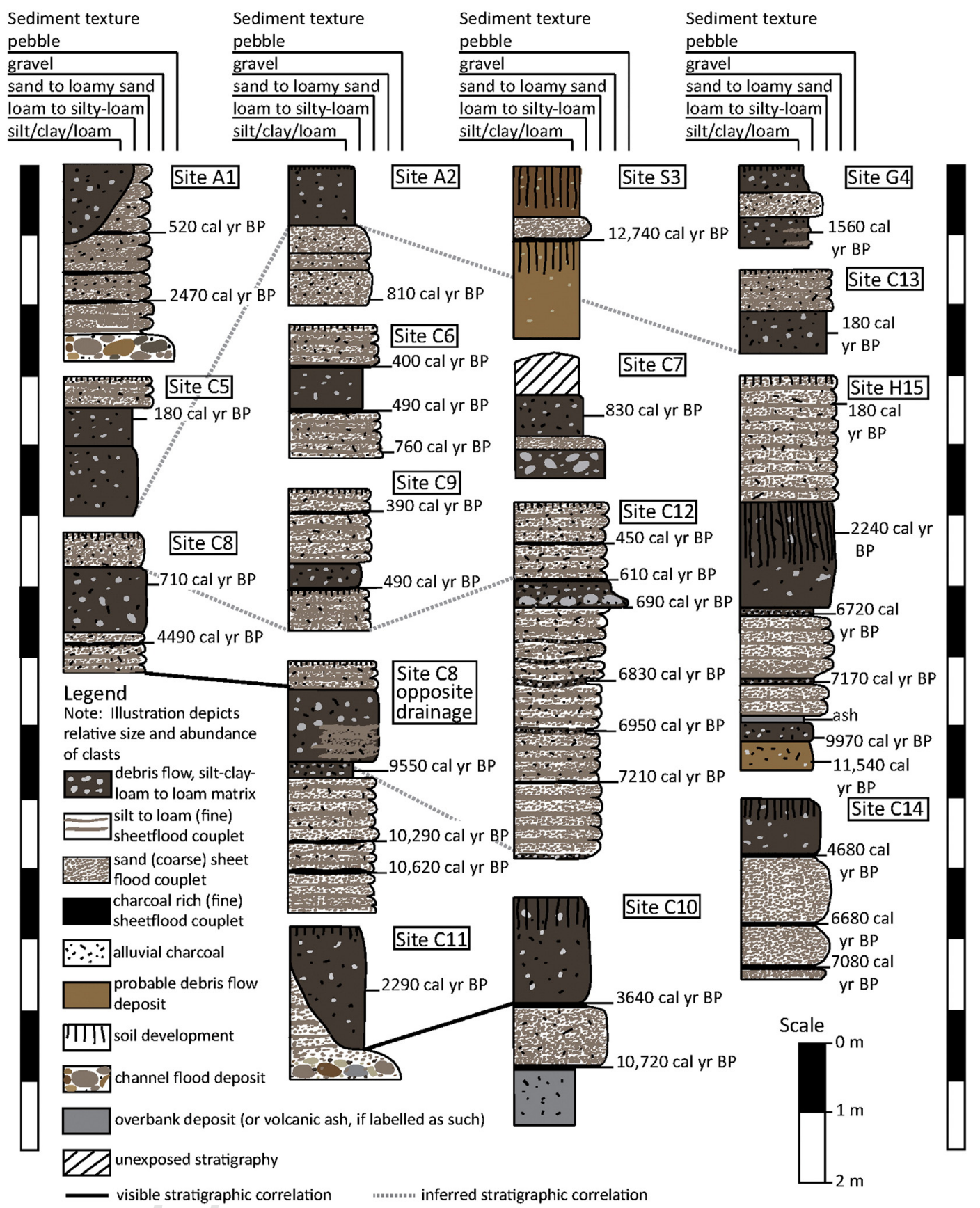

Figure 3. Summary illustration of the stratigraphic characteristics of each charcoal sampling site. Stratigraphic correlations between sites are shown by solid black lines for visible stratigraphic correlations and by dotted gray lines for inferred stratigraphic correlations. A black/white vertical scale is provided on each side of the figure.

\section{Discussion}

Holocene fire and vegetation at CIRO

The CIRO alluvial charcoal record shows both discrete peaks in fire activity and intervals of no fire-related sedimentation over the last 13,000 yr. Examination of the fire record within the context of vegetation change from local and regional woodrat midden series indicates that some peaks in fire activity correspond temporally with vegetation shifts. Independent regional records of Holocene climate change suggest that climate drives shifts in vegetation, fire regime and fire-related deposition. Below we discuss these trends within four characteristic time periods of the Holocene (Fig. 6).
Early Holocene (13,000-9500 cal yr BP)

Beginning 11,500 cal yr BP at CIRO, post-glacial climate warmed 371 abruptly (Davis et al., 1986; Murchison, 1989; Madsen et al., 2001; 372 Doner, 2009; Louderback and Rhode, 2009) and frequent fires pro- 373 duced charcoal mostly identified as juniper, which we assumed to 374 be Rocky Mountain juniper (Figs. 5a, 6). Regionally, lake charcoal re- 375 cords indicate that fire frequency increased throughout a wide range 376 of ecosystems in response to the drying and dying of Pleistocene veg- 377 etation (e.g., Millspaugh et al., 2000; Power et al., 2008a,b; Marlon et 378 Q8 al., 2009; Whitlock et al, 2012). Regional vegetation reconstructions 379 from pollen and midden records indicate increases in southern or 380 lower elevation plants 11,500-9500 cal yr BP (Fig. 6; Jackson et al., 381 


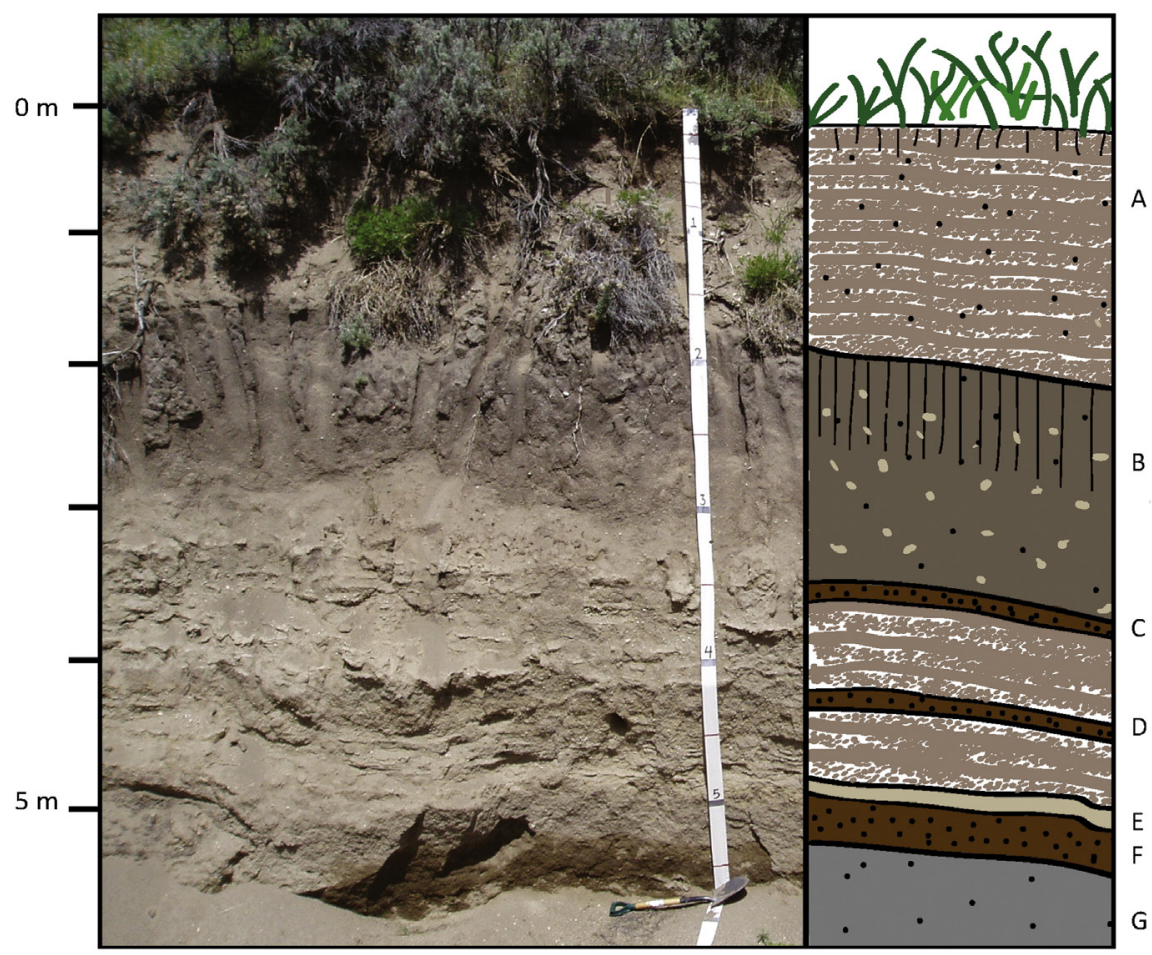

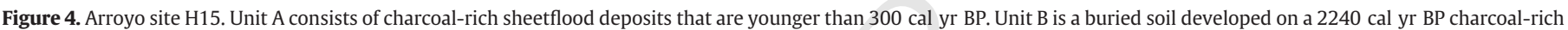

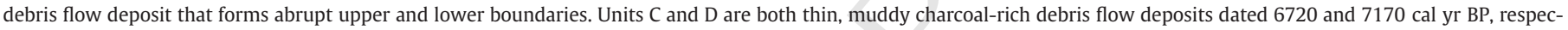

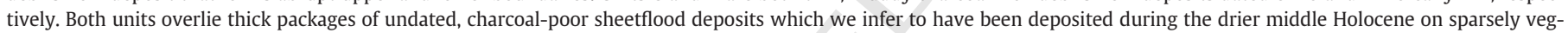

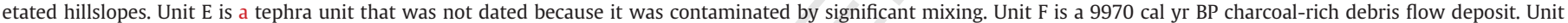
$\mathrm{G}$ is a thick 11,540 cal yr BP charcoal-rich debris flow deposit.

2005; Doner, 2009; Louderback and Rhode., 2009). During the same time, CIRO experienced a reduction in the dominance of limber pine and extirpation of mixed-conifer and subalpine elements. Seven fires were recorded at CIRO before $9500 \mathrm{cal} \mathrm{yr} \mathrm{BP.} \mathrm{Given} \mathrm{the} \mathrm{poor}$ preservation of charcoal and the lack of exposure of early Holocene stratigraphy, the actual number of fire-related sedimentation events probably was much higher (Surovell et al., 2009), indicating an interval of widespread and severe fires at CIRO.

\section{Early to Middle Holocene (9500-6500 cal yr BP)}

No fires were recorded at CIRO between 9500 and $7200 \mathrm{cal} \mathrm{yr} \mathrm{BP}$ (Fig. 5c) when regional climate was characteristically wetter and cooler, as indicated by lake records from Bear Lake, Idaho and the Uinta Range, Utah (Fig. 6; Moser and Kimball, 2009; Corbett and Munroe, 2010) and by a 8300 cal yr BP Lake Bonneville highstand, possibly $60 \mathrm{~m}$ higher than the Gilbert shoreline (Fig. 6; Oviatt, 1997; Patrickson et al., 2010). The highstand and other regional climate correspond to the "8.2 ka cool interval", a widely-recognized Heinrich event (e.g., Alley et al., 1997) that increased local snowpacks (Dean et al., 2002).

Climate began to warm $8200-4000$ cal yr BP (Louderback and Rhode, 2009) when regional midden records indicate decreased ecosystem productivity (Fig. 5b; Smith and Betancourt, 2003), Lake Bonneville was periodically low (Murchison, 1989), and pinyon-juniper (PJ) woodlands in the Great Basin inhabited elevations $500 \mathrm{~m}$ higher than today (Miller and Tausch, 2001). Records from Lake Bonneville and Bear Lake, however, suggest briefly wetter, cooler conditions beginning 7500 cal yr BP (Fig. 6; Murchison, 1989; Doner, 2009; Louderback and Rhode, 2009) that may have increased fuels for frequent fires between 7200 and 6700 cal yr BP at CIRO. Post-Mazama ( 7700 cal yr BP; Zdanowicz et al., 1999) increases in lake sediment charcoal $20 \mathrm{~km}$ north at higher elevation Lake Cleveland (Davis et al., 1986) corroborate the CIRO record, suggesting large and widespread fires (Fig. 6). Alluvial charcoal records from lodgepole forests in Yellowstone, south-central
Idaho sagebrush steppe, central Idaho lodgepole-dominated forests, 414 and central Idaho ponderosa forests also show increased fire activity be- 415 tween 7500 and 6200 cal yr BP (Fig. 7; Meyer et al., 1995; Meyer and 416 Q10 Pierce, 2003; Pierce et al., 2004; Nelson and Pierce, 2010; Riley, 2012) 417 during extended warmer, drier climate in the Rockies (Shuman et al., 418 2009).

Middle Holocene fires at CIRO may mark structural changes in vege- 420 tation; sampled charcoal macrofossils switched from mostly Rocky 421 Mountain juniper to 20\% Rocky Mountain juniper, $40 \%$ sagebrush and 422 $40 \%$ limber pine (Table 3; Fig. 5a). The geomorphic response also shifted 423 from episodic debris flows to frequent fire-related and charcoal-poor 424 sheetflooding events. Charcoal-poor sheetflooding suggests increased 425 hillslope erosion on sparsely vegetated (fuel-limited) hillslopes (Pierce 426 et al., 2004). In central Idaho, analogous post-fire sheetflooding was 427 recorded in the South Fork Payette and Middle Fork Salmon River drain- 428 ages during the 7500-6200 cal yr BP fires (Pierce et al., 2004; Riley, 429 2012). Unlike CIRO, the Payette and Salmon watersheds are character- 430 ized by steep, granitic hillslopes prone to post-wildfire debris flows. 431 However during this fire-prone period, debris flow activity was limited 432 and frequent sheetflood deposition occurred at the base of what are 433 now debris flow-prone, north-facing, and forested slopes (Meyer et al., 434 2001; Pierce et al., 2004; Riley, 2012).

Middle to Late Holocene (6500-2500 cal yr BP)

No fires were recorded at CIRO between 6700 and $4700 \mathrm{cal}$ yr BP dur- 437 ing regional, prolonged drought (Fig. 6; Murchison, 1989; Louderback and 438 Rhode, 2009; Shuman et al., 2009; Corbett and Munroe, 2010; Whitlock et 439 al., 2012), when upper treeline in the Albion Mountains reached maxi- 440 mum elevations at 4500 cal yr BP (Davis et al., 1986). At CIRO, low vege- 441 tation densities following previous fires, sustained by persistent drought, 442 inhibited fuel accumulation on hillslopes. Similar fire-free periods are reg- 443 istered in other alluvial charcoal records, suggesting that low fuel supplies 444 were regionally persistent (Fig. 7; Pierce et al., 2004; Nelson and Pierce, 445 


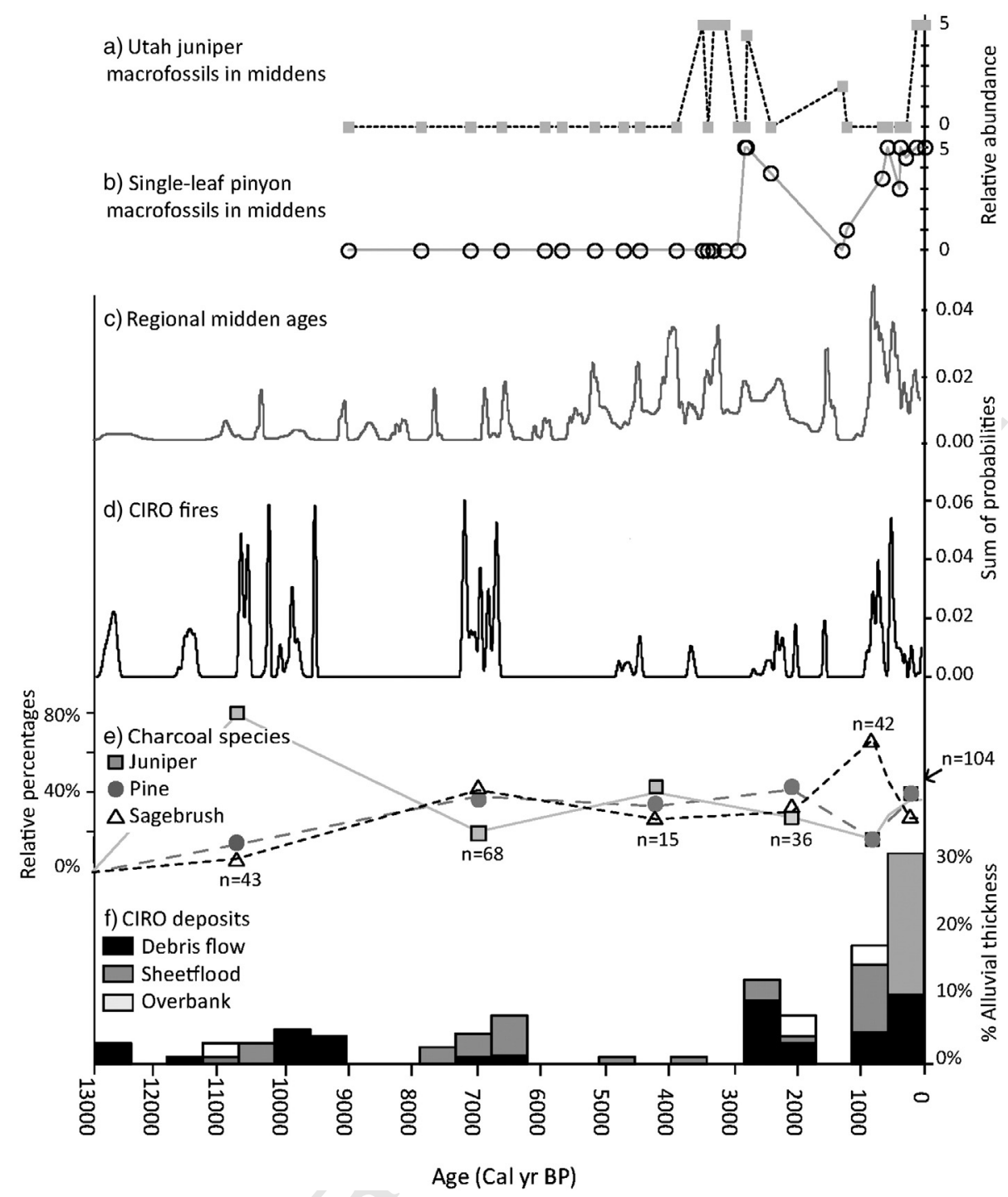

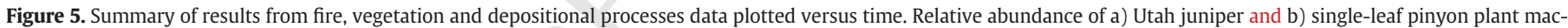

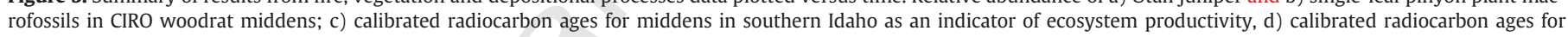

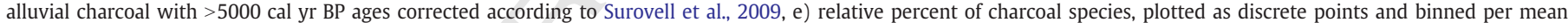
age of fire interval (dashed lines simply connect points), and f) stratigraphic record of percent alluvial thickness per depositional process.

2010; Svenson, 2010). In northeastern Yellowstone, however, fire activity increased beginning $~ 6500$ cal yr BP in a moist, densely vegetated ecosystem where past fires have been correlated with severe drought (Fig. 7; Meyer et al., 1995).

Fires at CIRO were infrequent between 4700 and 3600 cal yr BP when regional midden records suggest a return to cooler, wetter climate $4500-2000$ cal yr BP (Fig. 5b; Smith and Betancourt, 2003). Lake Bonneville shorelines elevated (Murchison, 1989), upper treeline descended in the Albion Mountains (Davis et al., 1986) and other regional paleoclimate records suggest cooler, wetter climate (Fig. 6; Madsen et al., 2001; Mensing et al., 2008; Louderback and Rhode, 2009). During this time, Utah juniper migrated to CIRO 3800 cal yr BP, followed by single-leaf pinyon $2800 \mathrm{cal} \mathrm{yr} \mathrm{BP} \mathrm{(Fig.} \mathrm{5c).}$

Westerling et al. (2011) predicts that as climate warms, fire rotation times will progressively decrease until there is insufficient time for forest regeneration between fire events. Eventually, fire strips the landscape of available fuels. This paradigm may be reflected in the CIRO record when frequent fires during the interval 7200-6700 cal yr BP were followed by no recorded fires until 4700 cal yr BP, potentially due to exhaustion of fuels accumulated during the earlier wetter interval. Prior to the $\sim 7200-6700$ cal yr BP fires, limber pine, Rocky
Mountain juniper and sagebrush occupied CIRO. Although single-leaf 467 pinyon had not yet arrived, estimates for post-fire regeneration of PJ 468 woodlands are 150-200 yr (Goodrich and Barber, 1999), while post- 469 fire sagebrush recovery takes 35-100 yr (Baker, 2006) and $>500 \mathrm{yr} 470$ are estimated for regeneration of limber pine forests (Rebertus et al., 471 1991). During the 7200-6700 cal yr BP fires, CIRO burned a minimum 472 of seven times. Although this frequency applies to the entire study 473 area (not individual basins), synchronous fire activity at nearby Lake 474 Cleveland (Davis et al., 1986) suggests widespread fires. This high fire 475 frequency may have exceeded the time interval needed for the regener- 476 ation of limber pine and Rocky Mountain juniper, and persistent warm 477 and dry conditions after $\sim 6700 \mathrm{cal}$ yr BP likely continued to reduced 478 vegetation densities and suppress fire.

Late Holocene (2500 cal yr BP-present)

Recent Holocene fires at CIRO burned when ecosystem productiv- 481 ity was high (e.g., denser forest and continuous fuels; Smith and 482 Betancourt, 2003; Fig. 5b) and correspond to regional droughts that 483 were preceded by above average moisture (Fig. 8). Frequent fires 484 


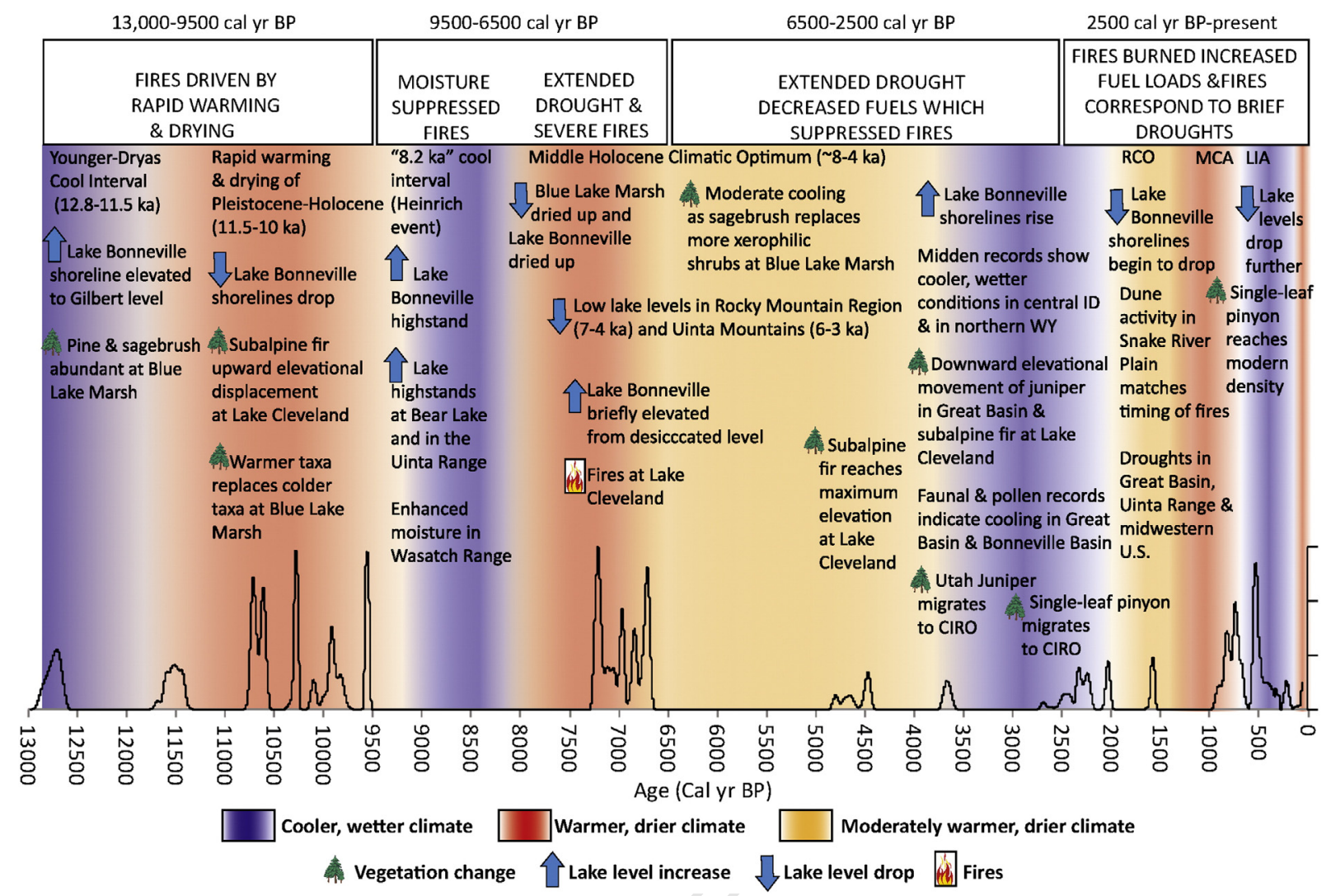

Figure 6. Summary of regional and global climate conditions compared with the CIRO fire record. The top of the figure references time periods discussed in the text and general fire trends from the CIRO charcoal record. The upper text of the climate summary shows widely recognized climatic variations within the Holocene (e.g., Lamb, 1972; Berger, 1978; Alley et al., 1997; Bianchi and McCave, 1999; Grove, 2001; Dean et al., 2002; Kaufman et al., 2004). RCO refers to the Roman Climate Optimum, MCA refers to the Medieval Climatic Anomaly and LIA refers to the Little Ice Age. Regional and local climate events are also shown (Davis et al., 1986; Murchison, 1989; Oviatt, 1997; Madsen et al., 2001; Dean et al., 2002; Smith and Betancourt, 2003; Gray et al., 2004; Jackson et al., 2005; Doner, 2009; Louderback and Rhode, 2009; Moser and Kimball, 2009; Shuman et al., 2009; Corbett and Munroe, 2010; Patrickson et al., 2010; Rittenour and Pearce, 2011).

burned during PJ expansion, indicating that fuel availability was likely no longer limiting fire at CIRO.

Fires that burned at CIRO between 2400 and 2000 cal yr BP correspond to $\sim 2$ ka drought (inferred from dune activation in the Snake River Plain, ID, Rittenour and Pearce, 2011), and to multidecadal droughts (2500 and 2200 cal yr BP) at Mission Cross Bog, NV (Fig. 8; Mensing et al., 2008). Comparison of CIRO fires after 1600 cal yr BP with reconstructed PDSI (Cook et al., 2004) indicates that all recorded fires were preceded by wetter than average conditions but ignition occurred during drought. These reconstructed PDSI droughts are corroborated by multiple climate records (Fig. 8; Gray et al., 2004; Stahle et al., 2007; Rittenour and Pearce, 2011). No fires were recorded between 1500 and $1000 \mathrm{cal}$ yr BP, when PDSI reconstruction indicates warmer but less variable climate (Fig. 8; Cook et al., 2004).

After its arrival, single-leaf pinyon expanded slowly and did not establish dominance across CIRO until 700 cal yr BP. Macrofossil evidence (Fig. 5a) suggests fires $\sim 850-700$ and $550-400$ cal yr BP burned mostly in stands of sagebrush; reduction in sage cover could have facilitated single-leaf pinyon infilling in rocky areas and encroachment on adjacent sagebrush stands that occupy deeper soils (Chambers, 2001).

Increased forest densities during the Little Ice Age (LIA) likely supplied fuel for the greatest recorded fire peak at CIRO 550$400 \mathrm{cal}$ yr BP, a fire peak that is also recorded in multiple regional alluvial charcoal records across a range of ecosystems in Idaho including the sagebrush steppe of Wood Creek (Nelson and Pierce, 2010), the ponderosa and Douglas fir dominated South Fork of the Payette (Pierce et al., 2004), the lodgepole pine to rangeland ecosystems of the Middle Fork of the Salmon River (Riley, 2012), and the lodgepole and mixed conifer forests of the Sawtooths (Fig. 7; Svenson, 2010).
While the timing of this fire peak is similar, these separate ecosys- 514 tems likely burned differently; for example, in the South Fork Payette, 515 frequent, low-severity fires typical of ponderosa pine and Douglas fir 516 forests were prevalent, although some of these fires were likely 517 stand-replacing (Fig. 7; Pierce et al., 2004). At CIRO, a new fire regime 518 likely took hold, and high-severity fires typical of PJ woodlands 519 (Baker and Shinneman, 2004; Romme et al., 2009) and sagebrush 520 steppe (Kauffman and Sapsis, 1989) produced multiple, fire-related 521 debris flow and sheetflood deposits that account for approximately 522 $50 \%$ of the total measured alluvial thickness (Fig. $5 \mathrm{f}$ ).

Holocene shifts in fire-related geomorphic response

The nature of Holocene alluvial deposits may reveal shifts in past 525 hillslope vegetation densities and the nature and severity of wildfires. 526 Unlike lake charcoal records, alluvial charcoal records are not contin- 527 uous; however, the episodic nature of alluvial deposition provides in- 528 sight into both fire activity and landscape response. For example, 529 modern and paleorecords of fire-related deposition have shown that 530 sheetfloods are characteristically deposited following low-severity 531 fires or following storms/fires on drier or south-facing slopes, where- 532 as post-fire debris flows often follow high-severity fires burning for- 533 ested slopes (Cannon et al., 2001a,b; Meyer et al., 2001; Pierce et al., 534 2004). Cannon et al. (2010) identified a $16.7^{\circ}$ slope threshold for de- 535 bris flow formation. Mean slopes at CIRO are $\sim 15.6^{\circ}$ indicating past 536 fires may not have generated debris flows on most hillslopes. Yet, 537 our record shows that episodic fire-related debris flows were depos- 538 ited during the early and late Holocene, but were rare between 7000539 


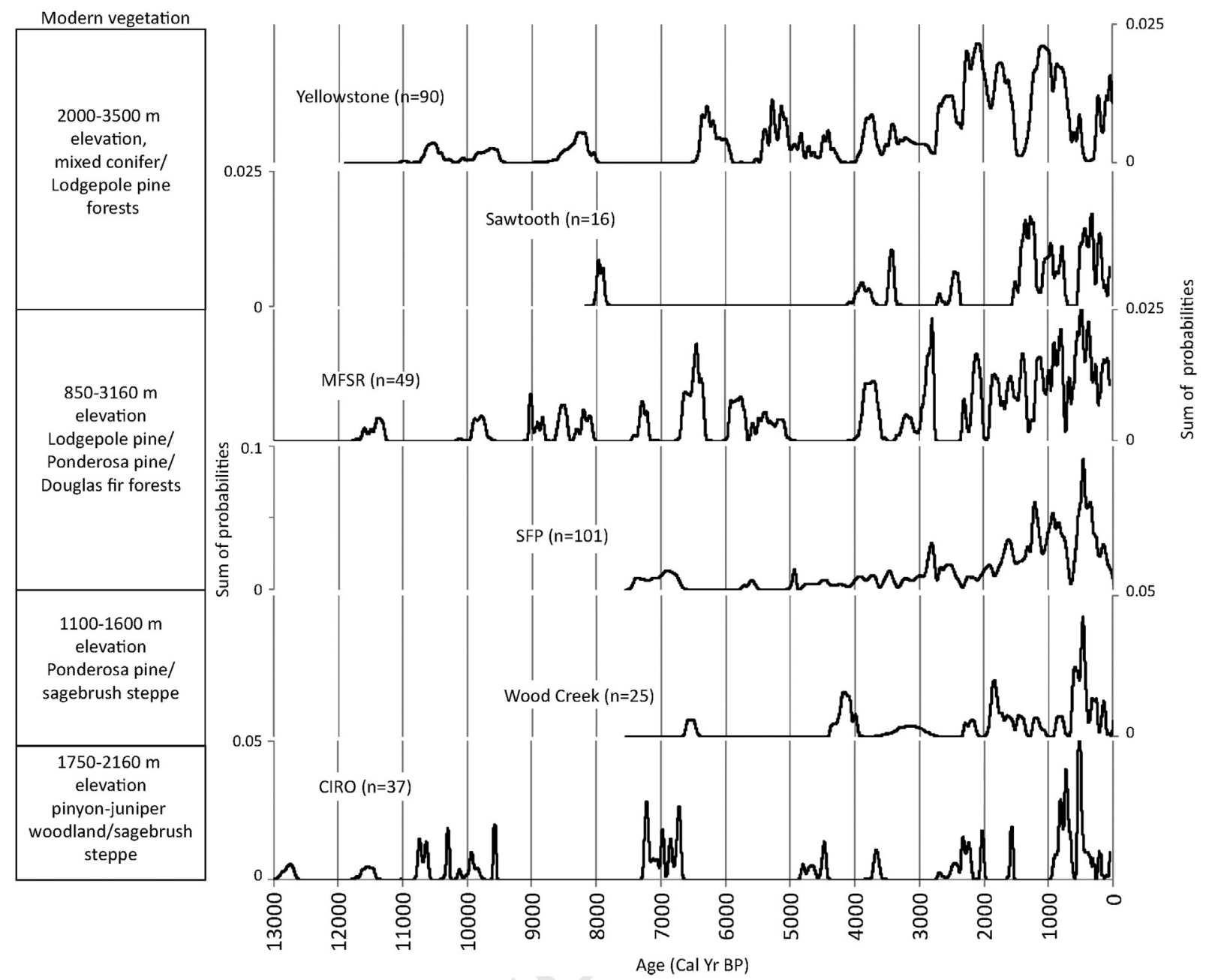

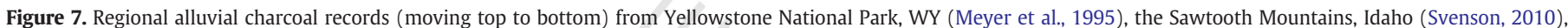

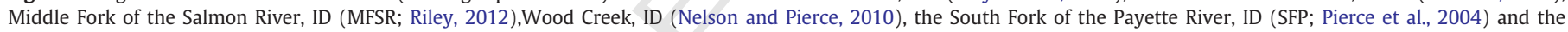

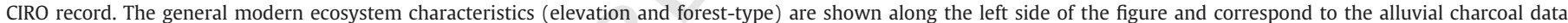

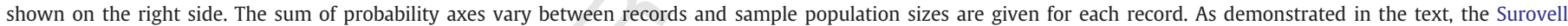

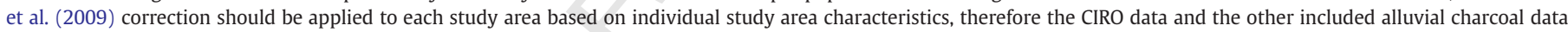
have not been corrected for taphonomic bias in this figure.

and 2500 cal yr BP when sheetfloods comprise the majority of deposits (Fig. 5d).

At CIRO, the notable absence of fire-related debris flow deposition between 7000 and $2500 \mathrm{cal}$ yr BP during warmer, drier climate (Fig. 4D) suggests several scenarios that are not mutually exclusive: 1 ) a discontinuous fuel source restricted fire size and severity; 2) frequent sheetflooding limited colluvial storage and soil development of in situ-weathered silt and clay-sized particles; and 3) the drier climate of the mid-Holocene restricted storm events needed to ignite fires and produce debris flows (Fig. 9). Unless the combined conditions of severe fire, adequate silt and clay-rich colluvium, and storms are met, our records indicate that debris flows are not common at CIRO.

The July insolation maximum (Berger, 1978) was manifested by regionally warmer, drier climate between $\sim 8$ and 4 ka that likely reduced hillslope vegetation density (Murchison, 1989; Louderback and Rhode, 2009; Shuman et al., 2009; Corbett and Munroe, 2010). Enhanced erosion rates have been attributed to drought-induced reductions in vegetation (Allen and Breshears, 1998). At CIRO, charcoalpoor sheetfloods constrained by deposits dated $6700-3600$ cal yr BP indicate that while enhanced sheetflood deposition occurred during droughty climate (Fig. 5d), this hillslope erosion was not triggered by fire. Despite dry conditions during this time, fire activity at CIRO was limited.
Between 8000 and $4000 \mathrm{cal}$ yr BP, sagebrush, Rocky Mountain juni- 563 per and limber pine occupied CIRO (Fig. 5a). These trees and shrubs do 564 not typically sustain low-severity fires during drier climate when 565 ground fuels are discontinuous (Baker and Shinneman, 2004; Mensing 566 et al., 2006; Romme et al., 2009). Fuel suppression by drought and/or 567 lack of ignition during convective storms may explain no-fire (and 568 low-fire) intervals during the bulk of this time frame. Mid-Holocene 569 fires (that produced thin, muddy debris flows and sheetfloods) were ig- 570 nited during drought following brief periods of increased moisture, 571 when accumulated fine fuels increased fuel connectivity for fire spread 572 on an otherwise sparsely-vegetated landscape. Nevertheless, low collu- 573 vial supply, diminished by frequent sheetflood deposition $(10,600-574$ 7200 cal yr BP), may have inhibited development of larger debris 575 flows. This combination of evidence (prolonged dry climate, thin 576 deposits, and limited fire-related deposition) 6700-4700 cal yr BP sug- 577 gests that the landscape had limited fuel, and low sediment supply on 578 hillslopes.

After 2400 cal yr BP, Utah juniper and single-leaf pinyon expanded 580 during wetter, cooler climate, fire activity increased and erosion shifted 581 back to episodic debris flow deposition. This erosional shift may be en- 582 tirely attributable to denser vegetation that changed fire regimes from 583 low-severity to high-severity fires. Evidence of soil development 584 $\sim 12,700,2300$ and 2200 cal yr BP also indicates more densely vegetated 585 


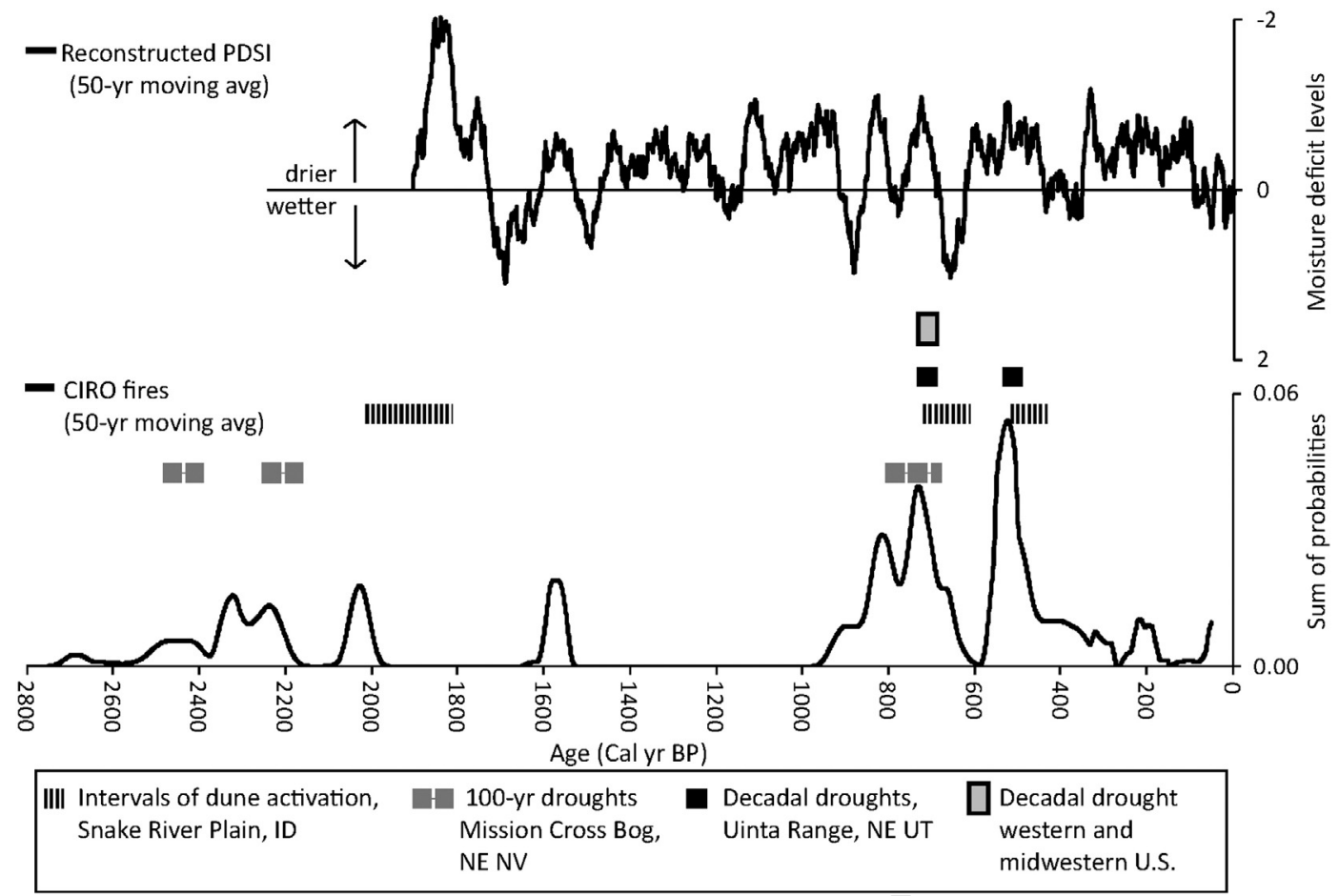

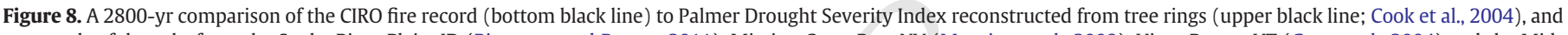

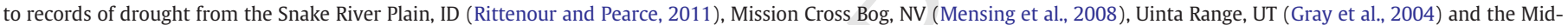
western U.S. (Stahle et al., 2007). To highlight longer term trends, fire and PDSI data were smoothed using a 50 year moving average in Microsoft Excel (50-yr moving avg).

and stabilized hillslopes. Stable well-developed soils would increase silt and clay content through loess-trapping and pedogenic processes, which also would increase the thickness of colluvium. Thick, welldeveloped soils, combined with ash production from fires, would provide both the mobile regolith and the fine-textural component necessary for debris flow development.

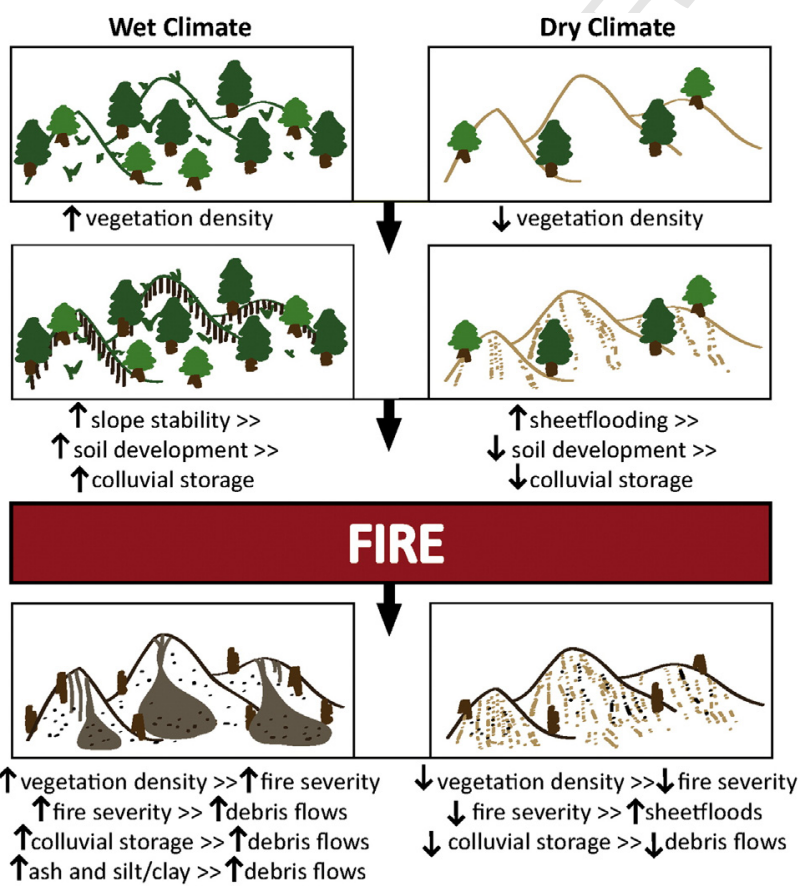

Figure 9. Conceptual model of feedbacks among wet climate vs. dry climate, vegetation, fire, and fire-related erosional response from burned hillslopes.
Broad-scale linkages among climate, vegetation and fire

Over the last few centuries in most areas in western North Amer- 593 ica, years of widespread burning in the observational or tree-ring re- 594 cord are associated with winter/spring drought, advanced timing of 595 snowmelt and greenup, and hot summers (Westerling et al., 2003, 596 2006; Heyerdahl et al., 2008; Littell et al., 2009; Falk et al., 2010; 597 Trouet et al., 2010; Gedalof, 2011). Well-resolved proxies for temper- 598 Q13 ature, precipitation and associated fire occurrence are too spotty in 599 the region to evaluate fire-climate relationships through the entire 600 Holocene.

Controls on fire-climate relationships, such as precession-driven 602 changes in insolation and the seasonal timing of moisture delivery, 603 have not been constant over the Holocene (e.g., Berger, 1978), and 604 changes in the seasonality of precipitation and summer convective 605 storms could broadly influence fire activity throughout the western 606 U.S. (e.g., Minckley et al., 2012; Brunelle et al., 2013). More impor- 607 tantly perhaps, precessional changes likely produced gradual shifts 608 in the annual phasing of regional temperatures. This may have affect- 609 ed the dominant controls of seasonal climate on wildland fire during 610 the Holocene, including the severity of winter/spring drought, the 611 timing of spring, and the intensity of summer heat loads. For example, 612 the shift from cooler to warmer winters into the late Holocene could 613 have advanced the onset of spring snowmelt and vegetative growth, 614 exhausting soil moisture and flammability earlier in the dry summer. 615 Finally, hydroclimatic areas with coherent, long-term variations in 616 temperature or precipitation, and thus decadal-scale or longer pat- 617 terns in fire synchrony, likely shifted with ocean temperatures over 618 the Holocene (Kitzberger et al., 2007).

CIRO $\left(\sim 42^{\circ} \mathrm{N}\right)$ lies in the transition zone $\left(40-42^{\circ} \mathrm{N}\right)$ of a north- 620 south dipole in regional precipitation (Dettinger et al., 1998; Brown 621 Q15 and Comrie, 2004; Wise, 2010; Pederson et al., 2011). During the 622 20th century, both the width and location of this transition shifted, 623 though the transition is most stable in the northern Great Basin, 624 where CIRO is located (see Shinker, 2010). The location of CIRO near 625 this dipole complicates comparison of the climatic controls on fire 626 
in this ecosystem with other studies investigating the climate drivers of fire in the western U.S.

In the introduction, it was suggested that multiproxy (climate, vegetation, fire, and alluvial) records like the one at CIRO, in comparison with other similar records across the region, could be used to sort out the chronological order and causal links between climate, vegetation, fire and erosional processes. Both the CIRO study and regional paleorecords lack the necessary specificity and resolution to fully account for the order and causality of multiple events and processes throughout the Holocene, but they do permit a few generalizations.

Throughout the Holocene, synchronous periods of fire activity throughout a range of diverse ecosystems in the northern Rockies indicate that widespread climate change, not specific vegetation migrations, drives fire activity. Other asynchronous fires periods suggest that local vegetation change (e.g., migrations or changes in fuel conditions) and/or regional climate variability also drives fires. For example, the prominent peak in fire activity in the CIRO record $\sim 10,700-9500$ cal yr BP is consistent with a pronounced peak in fire throughout many ecosystems (e.g., Power et al., 2008a,b; Marlon et al., 2009; Whitlock et al., 2012) in response to broadscale dieoffs of Pleistocene vegetation, consumption of the dead biomass by large and roughly synchronized fires, and accelerated erosion and sedimentation associated with broadscale biomass burning. The profound changes in both composition and structure of vegetation have been mostly directional and associated with regional warming, the decline of Pleistocene vegetation, and post-glacial reorganization (including plant migrations from both the south and lower elevations).

While many lake charcoal records show a general decrease in fire activity following the Pleistocene-Holocene transition (e.g., Power et al., 2008a,b; Marlon et al., 2009; Whitlock et al., 2012), alluvial charcoal records from CIRO and throughout the Northern Rocky Mountain region (e.g., Meyer et al., 1995; Pierce et al., 2004; Nelson and Pierce, 2010) are characterized by multi-century episodes of elevated fire occurrence punctuating multi-millennial intervals with little or no fire-related sedimentation. While most lake charcoal records do show this general decrease in fire activity following the Pleistocene-Holocene transition, both alluvial and lake records record a notable peak in fire activity during the mid-Holocene ( 7500-5000 cal yr BP). For example, elevated charcoal levels were recorded $~ 7500-6500 \mathrm{cal}$ yr BP at both CIRO and at higher elevation Lake Cleveland, $20 \mathrm{~km}$ north of CIRO (Davis et al., 1986). This mid-Holocene peak is recorded in other alluvial charcoal records in central Idaho (Pierce et al., 2004; Riley, 2012), and in lake charcoal records throughout the Northern Rocky Mountains (e.g., Power et al., 2011), likely in response to regional drought conditions (Fig. 6; Murchison, 1989; Louderback and Rhode, 2009; Shuman et al., 2009; Corbett and Munroe, 2010; Whitlock et al., 2012).

Asynchronous peaks in fire activity among different vegetation types during the late Holocene likely indicate that local vegetation and climate changes also play an important role in driving regional pulses in fire and fire-related sedimentation. At CIRO, however, we cannot precisely order, and therefore relate, the late Holocene colonization and expansion by $\mathrm{PJ}$ woodland with peaks in the alluvial charcoal record 2400-2000, 850700, and 550-400 cal yr BP. At CIRO, and elsewhere along the northern peripheries of PJ woodlands, fire and other ecological disturbances associated with regional multi-decadal droughts during the Medieval Climate Anomaly could have enhanced colonization and expansion of Utah juniper and single-leaf pinyon. The densification of pinyon-juniper (PJ) woodland at CIRO over the last millennium likely and uniquely increased the likelihood of local crown fires. In the future, the combination of dense PJ woodland and cheatgrass invasion at CIRO could, in fact, produce a sustained shift in fire and fire-related erosion and sedimentation.

\section{Management implications}

Consistent with historical observations of PJ expansion in the western U.S. (Romme et al., 2009), repeat photography documents
PJ density increases and downslope infilling at CIRO during the last 691 $\sim 150$ yr (Morris, 2006). Our study documents accelerated PJ infilling 692 at CIRO beginning 700 cal yr BP, long before Euro-American settle- 693 ment of CIRO commenced in 1888 AD. This long-term PJ expansion 694 at CIRO relates largely to climate-driven expansion and/or natural 695 post-glacial vegetation colonization, and falls within the natural 696 range and variability of this system. However, PJ expansion is often 697 attributed to land use practices that include fire exclusion and live- 698 stock grazing, which may be enhancing modern tree densities 699 (e.g., Shinneman and Baker, 2009; Powell et al., 2013).

At CIRO, fire has been a natural component of PJ woodlands since col- 701 onization, and fires were most frequent after PJ populations expanded 702 700 years ago. High-severity fires in dense PJ stands shifted erosional 703 processes from sheetflooding to more catastrophic debris flows. Modern 704 stand densities suggest increased risk of severe fires. For example, dur- 705 ing the summer of 2001, a 71- $\mathrm{km}^{2}$ mixed-severity fire that burned 706 into the southern portion of CIRO was indeed stand-replacing and light- 707 ning caused, indicating that given adequate ignition, the CIRO PJ wood- 708 lands are ripe to burn. Along with fire damage, fire-related debris flows 709 would likely extend beyond burned areas, threatening park structures 710 and infrastructure.

711

\section{Conclusions}

712

Climatically-modulated changes in vegetation, fire regimes and 713 geomorphic processes during the last 13,000 yr are inferred from al- 714 luvial charcoal and woodrat midden records from CIRO. These records 715 reveal fuel and drought controlled fire peaks in the early and late Ho- 716 locene, and low fire activity in the dry fuel-limited mid-Holocene. In 717 addition, alternations between debris flows and sheetfloods exposed 718 in alluvial stratigraphic records reveal variations in erosional re- 719 sponse to intense stand-replacing fires burning dense vegetation vs. 720 less severe fires burning lower fuel-loads.

Fires (10,700-9500 cal yr BP) that produced thick debris flow de- 722 posits containing abundant Rocky Mountain juniper macrofossils cor- 723 respond to warming climate of the Pleistocene-Holocene transition. 724 Dense late-glacial juniper forests supplied fuel and colluvium for ep- 725 isodic debris flow deposition following large, high severity fires. Re- 726 gional climate records indicate an overall cooler/wetter climate 727 12,700-8000 cal yr BP, particularly when compared with middle 728 and late Holocene climates. This suggests that 10,700-9500 cal yr BP 729 fires burned dense fuels that were ignited during episodic drought. 730

During the warmer, drier climate of the mid-Holocene $(\sim 8000-731$ 4000 cal yr BP), fire activity was generally low, with the notable ex- 732 ception of the interval between 7200 and 6700 cal yr BP. Thick pack- 733 ages of fire-related sheetfloods from this interval contain macrofossils 734 of limber pine, Rocky Mountain juniper and sagebrush. Other regional 735 records show a peak in fire activity $~ 7.5-6 \mathrm{ka}$, possibly due to in- 736 creased fuel loads and/or increased ignitions during a wetter interval 737 in the otherwise dry and stable mid-Holocene.

According to Great Salt Lake and other paleorecords, arrivals of Utah 739 juniper ( $3800 \mathrm{cal} \mathrm{yr} \mathrm{BP})$ and single-leaf pinyon ( $2800 \mathrm{cal} \mathrm{yr} \mathrm{BP}) 740$ was associated with cooler, wetter conditions during the late Holocene. 741 Note, however, that in the Wyoming Basins, late Holocene Utah juniper 742 migration was associated instead with drought in the central Plains 743 (Lyford et al., 2003). It is unclear whether this signifies regional differ- 744 ences between the northern Great Basin and the Great Plains, or more 745 likely the northward expansion of Utah juniper (and pinyon) is being 746 driven by synchronous warming across both regions. 747

Nevertheless, following PJ migration, clusters of debris flow- 748 producing fires were recorded at 2400-2000, 850-700, and 550- 749 $400 \mathrm{cal}$ yr BP that burned during annual to decadal droughts preceded 750 by annual to decadal intervals of above average moisture (Cook et al., 751 2004). This suggests that variable climate shifted both vegetation and 752 fire regime, where high severity fires in dense PJ were no longer limited 753 by fuel availability but rather by likelihood of ignition. PJ expansion 754 
stabilized hillslopes and provided ample colluvial supply for post-fire debris flow deposition. Although the gently-sloping, granitic terrain at CIRO is not conducive to debris flow development, episodic fire-related debris flows deposited during the early and late Holocene suggest that fire has pushed erosional responses past geomorphic thresholds.

Fires recorded 550-400 cal yr BP at CIRO and in multiple regional alluvial charcoal records (Pierce et al., 2004; Nelson and Pierce, 2010; Svenson, 2010; Riley, 2012) implies significant regional climate forcings. During the LIA, large fires that produced debris flows burned when cooler, wetter conditions were punctuated by severe droughts (Cook et al., 2004). Although these fires burned at roughly the same time under similar climate conditions, the nature of these fires varied according to ecosystem and pre-fire fuel conditions.

At the beginning of this paper, we raised the question of which comes first, the shift in fire and erosion regime or the change in vegetation? Our record indicates since PJ colonization of CIRO, high-severity wildfires have burned dense fuel loads that accumulated and subsequently dried during periods of variable climate. In the last 150 yr, PJ woodlands have increased in density and expanded into neighboring vegetation communities at CIRO (Morris, 2006) and throughout the western U.S. (Romme et al., 2009). High tree densities and near-continuous cheatgrass cover through the woodland and adjacent open lands have increased the risk of crown fires and fire-related debris flows at CIRO. This elevated fire risk will be exacerbated by earlier and warmer growing seasons, and an increased potential for climate extremes in both precipitation and temperatures caused by amplified levels of atmospheric greenhouse gases (e.g., Groisman et al., 2005; Duffy and Tebaldi, 2012).

\section{Acknowledgments}

Funding was provided by the Idaho EPSCoR Program and the National Science Foundation (award \# EPS-0814387 to Pierce), Bureau of Land Management, the National Park Service/U.S. Geological Survey Park Oriented Biological Support (POBS) Program (award to Betancourt), and the City of Rocks National Reserve and Boise State University. Special thanks to Lesley Morris for bringing this group together, Wallace Keck and Kristen Bastis for administrative and logistic support at CIRO, Austin Hopkins for field assistance and James McMurtry for musical inspiration. Kate A. Rylander contributed to the midden analysis. Erica Bigio (University of Arizona) provided valuable comments. The study benefited from discussions with Doug Shinneman, and was improved by the thoughtful comments of two anonymous reviewers. Radiocarbon dates were provided by AMS Laboratories at University of Arizona and W.M. Keck Carbon Cycle Lab, University of California, Irvine.

\section{References}

Adams, K.R., Murray, S.S., 2011. Identification criteria for plant remains recovered from archaeological sites in the Central Mesa Verde Region. [HTML Title]. Available: http://www.crowcanyon.org/plantID (Date of use: 2011).

Allen, C.D., 2007. Interactions across spatial scales among forest dieback, fire, and erosion. Ecosystems 10, 797-808.

Allen, C.D., Breshears, D.D., 1998. Drought-induced shift of a forest woodland ecotone: rapid landscape response to climate variation. Proceedings of the National Academy of Science 95, 14839-14842.

Alley, R.B., Mayewski, P.A., Sowers, T., Stuiver, M., Taylor, K.C., Clark, P.U., 1997. Holocene climatic instability: a prominent, widespread event 8,200 years ago. Geology $25,483-486$.

Automated Georeference Center, 2001. HistoricLakeBonneville (SGID93 Water), State of Utah SGID. AGRC, Salt Lake City, UT (ftp://ftp.agrc.utah.gov/SGID93_Vector/ NAD83/MetadataHTML/SGID93_WATER_HistoricLakeBonneville.html)

Baker, W.L., 2006. Fire and restoration of sagebrush ecosystems. Wildlife Society Bulletin 34, 177-185.

Baker, W.L., Shinneman, D.J., 2004. Fire and restoration of piñon-juniper woodlands in the western United States: a review. Forest Ecology and Management 189, 1-21.

Berger, A.L., 1978. Long-term variations of daily insolation and Quaternary climatic changes. Journal of the Atmospheric Sciences 35, 2362-2367.

Betancourt, J.L., Van Devender, T.R., Martin, P.S. (Eds.), 1990. Packrat Middens: The Last 40,000 Years of Biotic Change. University of Arizona Press, Tucson (472 pp.).
Bianchi, G.G., McCave, I.N., 1999. Holocene periodicity in North Atlantic climate and 821 deep-ocean flow south of Iceland. Nature 397 (6719), 515-517.

Birkeland, P.W., Machette, M.N., Haller, K.M., 1991. Soils as a tool for applied Quaternary 823 geology. Utah Geological and Mineral Survey Miscellaneous Publication 91-3, 44.824

Brown, D.P., Comrie, A.C., 2004. A winter precipitation "dipole" in Western United 825 States associated with multidecadal ENSO variability. Geophysical Research Letters 826 31, 1-4.

Brunelle, A., Minckley, T.A., Lips, E., Burnett, P., 2013. A record of Lateglacial/Holocene 828 environmental change from a high-elevation site in the Intermountain West, 829 USA. Journal of Quaternary Science 28, 103-112.

Cannon, S.H., Bigio, E.R., Mine, E., 2001a. A process for fire-related debris flow initiation, 831 Cerro Grande fire, New Mexico. Hydrological Processes 15, 3011-3023.

Cannon, S.H., Kirkham, R.M., Parise, M., 2001b. Wildfire-related debris-flow initiation 833 processes, Storm King Mountain, Colorado. Geomorphology 39, 171-188.

Cannon, S.H., Gartner, J.E., Rupert, M.G., Michael, J.A., Rea, A.H., Parrett, C., 2010. 835 Predicting the probability and volume of post wildfire debris flows in the 836 intermountain western United States. Geological Society of America Bulletin 122, 837 127-144.

Chambers, J.C., 2001. Pinus monophylla establishment in an expanding Pinus-Juniperus 839 woodland: environmental conditions, facilitation and interacting factors. Journal of 840 Vegetation Science 12, 27-40.

City Of Rocks National Reserve Vegetation Maphttp://www.usgs.gov/core science 842 systems/csas/vip/parks/ciro.html. ark, J.S., Royall, P.D., Chumbley, C., 1996. The role of fire during climate change in an 844 eastern North American forest at Devil's Bathtub, New York. Ecology 77, 845 2148-2166.

Cook, E.R., Woodhouse, C.A., Easkin, C.M., Meko, D.M., Stahle, D.W., 2004. Long-term 847 aridity changes in the western United States. Science 306, 1015-1018. 848

Corbett, L.B., Munroe, J.S., 2010. Investigating the influence of hydrogeomorphic setting 849 on the response of lake sedimentation to climatic changes in the Uinta Mountains, 850 Utah, USA. Journal of Paleolimnology 44, 311-325.

Davis, O.K., Sheppard, J.C., Robertson, S., 1986. Contrasting climatic histories for the 852 Snake River Plain, Idaho, resulting from multiple thermal maxima. Quaternary Re- 853 search 26, 321-329.

Dean, W.E., Forester, R.M., Bradbury, J.P., 2002. Early Holocene change in atmospheric 855 circulation in the Northern Great Plains: an upstream view of the 8.2 ka cold 856 event. Quaternary Science Reviews 21, 1763-1775.

Dettinger, M.D., Cayan, D.R., Diaz, H.F., Meko, D.M., 1998. North-south precipitation 858 patterns in western North America on interannual-to-decadal time scales. Journal 859 of Climate 11, 3095-3111.

Doner, L.A., 2009. A 19,000-year vegetation and climate record for Bear Lake, Utah and 861 Idaho in paleoenvironments of Bear Lake, Utah and Idaho, and its catchment. Geo- 862 logical Society of America Special Paper 450, 217-227.

Duffy, P.B., Tebaldi, C., 2012. Increasing prevalence of extreme summer temperatures in 864 the U.S. Climatic Change 111, 487-495.

Falk, D.A., Heyerdahl, E.K., Brown, P.M., Swetnam, T.W., Sutherland, E.K., Gedalof, Z., 866 Yocom, L. Brown, TJ, 2010. Fire and climate variation in western North America 867 from fire-scar and tree-ring networks. PAGES 18, 70-72.

Folk, R.L., 1965. Petrology of Sedimentary Rocks. Hemphill Publishing Company, Austin, 869 TX.

Gavin, D.G., 2001. Estimation of inbuilt age in radiocarbon ages of soil charcoal for fire 871 history studies. Radiocarbon 43, 27-44.

Gedalof, Z., 2011. Climate and spatial patterns of fire in North America. In: McKenzie, 873 D., Miller, C., Falk, D.A. (Eds.), The Landscape Ecology of Fire. Springer, New York, Q20 pp. 89-115.

Goodrich, S., Barber, B., 1999. Return interval for PJ following fire in the Green River 876 corridor, near Dutch John, Utah. In: Monsen, S.B., Stevens, R. (Eds.), Proceedings: 877 Ecology and Management of PJ Communities Within the Interior West. United States 878 Department of Agriculture Forest Service, Proceedings, RMRS-P-9, pp. 391-393. 879

Gray, S.T., Jackson, S.T., Betancourt, J.L., 2004. Tree-ring based reconstructions of 880 interannual to decadal-scale precipitation variability for northeastern Utah since 881 1226 A.D. Journal of the American Water Resources Association 40, 947-960. 882 Grissino-Mayer, H.D., Swetnam, T.W., 2000. Century scale climate forcing of fire re- 883 gimes in the American Southwest. The Holocene 10, 213-220.

Groisman, P.Y., Knight, R.W., Easterling, D.R., Karl, T.R., Hegerl, G.C., Razuvaev, V.N., 885 2005. Trends in intense precipitation in the climate record. Journal of Climate 18, 886 $1326-1350$.

Grove, J.M., 2001. The initiation of the "Little Ice Age" in regions round the North Atlan- 888 tic. Climate Change 48, 53-82.

Heyerdahl, E.K., Brubaker, L.B., Agee, J.K., 2002. Annual and decadal climate forcing of 890 historical fire regimes in the interior Pacific Northwest, USA. The Holocene 12, 891 597-604

Heyerdahl, E.K., Morgan, P., Riser, J.P., 2008. Multi-season climate synchronized 893 historical fires in dry forests (1650-1900), Northern Rockies, USA. Ecology 89, 894 705-716

Jackson, S.T., Betancourt, J.L., Lyford, M.E., Gray, S.T., Rylander, K.A., 2005. A 40,000 year 896 woodrat midden record of vegetational and biogeographic dynamics in north- 897 eastern Utah, USA. Journal of Biogeography 32, 1085-1106.

John, T., 1995. Vascular flora of City of Rocks and vicinity - a preliminary checklist. [No 899 Publisher] Published Report 132206.

Kauffman, J.B., Sapsis, D.B., 1989. The natural role of fire in Oregon's High Desert. 901 Oregon's High Desert: The Last 100 Years. 1989 Range Field Day Report. June 902 1989. Special Report, 841. Oregon State University, Corvallis, OR, pp. 15-19. 903

Kaufman, D.S., Ager, T.A., Anderson, N.J., Anderson, P.M., Andrews, J.T., Bartlein, P.J., 904 Brubaker, L.B., Coats, L.L., Cwynar, L.C., Duvall, M.L., Dyke, A.S., Edwards, M.E., 905 Eisner, W.R., Gajewski, K., Geirsdottir, A., Hu, F.S., Jennings, A.E., Kaplan, M.R., 906 
Kerwin, M.W., Lozhkin, A.V., MacDonald, G.M., Miller, G.H., Mock, C.J., Oswald, W.W., Otto-Bliesner, B.L., Porinchu, D.F., Ruhland, K., Smol, J.P., Steig, E.J., Wolfe, B.B., 2004. Holocene thermal maximum in the western Arctic $(0-180$ W). Quaternary Science Reviews 23 (5-6), 529-560.

Keeley, J.E., Aplet, G.H., Christensen, N.L., Conard, S.G., Johnson, E.A., Omi, P.N., Peterson, D.L., Swetnam, T.W., 2009. Ecological Foundations for Fire Management in North American Forest and Shrubland Ecosystems. USDA Forest Service, Pacific Northwest Research Station, p. 92.

Kitzberger, T., Brown, P.M., Heyerdahl, E.K., Swetnam, T.W., Veblen, T.T., 2007. Contingent Pacific-Atlantic ocean influence on multi-century wildfire synchrony over western North America. Proceedings of the National Academy of Sciences 104 543-548.

Lamb, H.H., 1972. Climate: present, past and future. Fundamentals and Climate Now, volume 1. Methuen, London (613 pp.).

Littell, J.S., McKenzie, D., Peterson, D.L., Westerling, A.L., 2009. Climate and wildfire area burned in western U.S. Ecoprovinces, 1916-2003. Ecological Applications 19, 1003-1021.

Louderback, L.A., Rhode, D.E., 2009. 15,000 years of vegetation change in the Bonneville basin: the Blue Lake pollen record. Quaternary Science Reviews 28, 308-326.

Lyford, M.E., Jackson, S.T., Betancourt, J.L., Gray, S.T., 2003. Influence of landscape structure and climate variability on a late Holocene plant migration. Ecological Monographs 73 (4), 567-583.

Madsen, D.B., Rhode, D., Grayson, D.K., 2001. Late Quaternary environmental change in the Bonneville basin, western USA. Palaeogeography, Palaeoclimatology, Palaeoecology 167, 243-271.

Marlon, J.R., Bartlein, P.J., Walsh, M.K., Harrison, S.P., Brown, K.J., Edwards, M.E., Higuera, P.E., Power, M.J., Anderson, R.S., Briles, C., Brunelle, A., Carcaillet, C., Daniels, M., Hu, F.S., Lavoie, M., Long, C., Minckley, T., Richard, P.J.H., Scott, A.C., Shafer, D.S., Tinner, W., Umbanhowar Jr., C.E., Whitlock, C., 2009. Wildfire responses to abrupt climate change in North America. Proceedings of the National Academy of Sciences 106, 2519-2524.

Mensing, S., Livingston, S., Barker, P., 2006. Long-term fire history in Great Basin sagebrush reconstructed from macroscopic charcoal in spring sediments, Newark Valley, Nevada. Western North American Naturalist 66, 64-77.

Mensing, S., Smith, J., Norman, K.B., Allan, M., 2008. Extended drought in the Great Basin of western North America in the last two millennia reconstructed from pollen records. Quaternary International 188, 79-89.

Meyer, G.A., Wells, S.G., Jull, A.J.T., 1995. Fire and alluvial chronology in Yellowstone National Park: climatic and intrinsic controls on Holocene geomorphic processes. Geological Society of America Bulletin 107, 1211-1230.

Meyer, G.A., Pierce, J.L., Wood, S.H., Jull, A.J.T., 2001. Fire, storms, and erosional events in the Idaho batholith. Hydrological Processes 15, 3025-3038.

Miller, R.F., Tausch, R.J., 2001. The role of fire in juniper and pinyon woodlands: a descriptive analysis. In: Galley, K.E.M., Wilson, T.P. (Eds.), Proceedings of the Invasive Species Workshop: The Role of Fire in the Control and Spread of Invasive Species. Fire Conference 2000: The First National Congress on Fire Ecology, Prevention, and Management. Miscellaneous Publication No. 11. Tall Timbers Research Station, Tallahassee, FL, pp. 15-30.

Miller, D.M., Armstrong, R.L., Bedford, D.R., Davis, M., 2008. Geologic map and digital data base of the Almo quadrangle and City of Rocks National Reserve, Cassia County, Idaho. U.S. Geological Survey Open-File Report 2008-1103, 36 p., 1 sheet, scale $1: 24,000$.

Millspaugh, S.H., Whitlock, C., Bartlein, P.J., 2000. Variations in fire frequency and climate over the past $17000 \mathrm{yr}$ in central Yellowstone National Park. Geology 28, 211-214.

Minckley, T.A., Shriver, R.K., Shuman, B., 2012. Resilience and regime change in a southern Rocky Mountain ecosystem during the past 17000 years. Ecological Monographs 82, 49-68.

Monitoring Trends in Burn Severity Data Access, 2011. Fire level geospatial data. MTBS Project.USDA Forest Service/U.S. Geological Survey.

Morris, L., 2006. The Ecological History of the City of Rocks National Reserve Part 1: The Human Archive. Utah State University (Dissertation).

Moser, K.A., Kimball, J.P., 2009. A 25,000 year record of hydrologic and climatic change inferred from diatoms from Bear Lake, Utah/Idaho, USA' in paleoenvironments of Bear Lake, Utah and Idaho, and its catchment. Geological Society of America Special Paper 450, 229-246

Murchison, S.B., 1989. Fluctuation History of the Great Salt Lake, Utah, During the Last 13,000 Years. University of Utah (Ph.D. dissertation)

Nelson, N.A., Pierce, J.L., 2010. Late-Holocene relationships among fire, climate and vegetation in a forest-sagebrush ecotone of southwestern Idaho, USA. The Holocene 20, 1179-1194.

Oviatt, C.G., 1997. Lake Bonneville fluctuations and global climate change. Geology 25 , $155-158$.

Patrickson, S.J., Sack, D., Brunelle, A.R., Moser, K.A., 2010. Late Pleistocene to early Holocene lake level and paleoclimate insights from Stansbury Island, Bonneville basin, Utah. Quaternary Research 73, 237-246.

Pederson, G.T., Gray, S.T., Woodhouse, C.A., Betancourt, J.L., Fagre, D.B., Littell, J.S., Watson, E., Luckman, B.H., Graumlich, L.J., 2011. The unusual nature of recent snowpack declines in the North American Cordillera. Science 15, 332-335.

Pierce, J.L., Meyer, G.A., Jull, A.J.T., 2004. Fire-induced erosion and millennial-scale climate change in northern ponderosa pine forests. Nature 432, 87-90.

Pogue, K.R., Katz, C., 2008. Etched in Stone: The Geology of City of Rocks National Reserve and Castle Rocks State Park, Idaho. Idaho Geological Survey.

Powell, S.L., Hansen, A.J., Rodhouse, T.J., Garrett, Betancourt, J.L., L.K., Dicus, G.H., Lonneker, M.K., 2013. Woodland dynamics at the northern range periphery: challenge for protected area managers. PLoS One.
Power, M.J., Marlon, J., Ortiz, N., Bartlein, P.J., Harrison, S.P., Mayle, F.E., Ballouche, A., 993 Bradshaw, R.H., Carcaillet, C., Cordova, C., Mooney, S., Moreno, P., Prentice, I.C., 994 Thonicke, K., Tinner, W., Whitlock, C., Zhang, Y., Zhao, Y., Ali, A.A., Anderson, R.S., 995 Beer, R., Behling, H., Briles, C., Brown, K.J., Brunelle, A., Bush, M., Camill, P., Chu, 996 G.Q., Clark, J., Colombaroli, D., Connor, S., Daniau, A.L., Daniels, M., Dodson, J., 997 Doughty, E., Edwards, M.E., Finsinger, W., Foster, D., Frechette, J., Gaillard, M.J., 998 Gavin, D.G., Gobet, E., Haberle, S., Hallett, D.J., Higuera, P., Hope, G., Horn, S., 999 Inoue, J., Kaltenrieder, P., Kennedy, L., Kong, Z.C., Larsen, C., Long, C.J., Lynch, J., 1000 Lynch, E.A., McGlone, M., Meeks, S., Mensing, S., Meyer, G., Minckley, T., Mohr, J., 1001 Nelson, D.M., New, J., Newnham, R., Noti, R., Oswald, W., Pierce, J., Richard, P.J.H., 1002 Rowe, C., SanchezGoñi, M.F., Shuman, B.J., Takahara, H., Toney, J., Turney, C., 1003 Urrego-Sanchez, D.H., Umbanhowar, C., Vandergoes, M., Vanniere, B., Vescovi, E., 1004 Walsh, M., Wang, X., Williams, N., Wilmshurst, J., Zhang, J.H., 2008a. Changes in 1005 fire regime since the Last Glacial Maximum: an assessment based on a global 1006 synthesis and analysis of charcoal data. Climate Dynamics 30, 887-907. 1007

Power, M.J., Whitlock, C., Bartlein, P.J., 2008b. Postglacial fire, vegetation, and climate 1008 history across an elevational gradient in the Northern Rocky Mountains, USA and 1009 Canada. Quaternary Science Reviews 30, 2520-2533.

Rebertus, AJ Burns, B R Veblen, TT 1991. Stand dynamics of Pinus flexilis-dominated subalpine forests in the Colorado Front Range. Journal of Vegetation Science 2, 1012 $445-458$.

Riley, K, 2012. A 14,000 Year Record of Fire and Alluvial Fan Deposition Reveal Rela- 1014 tionships Among Fire, Climate, Vegetation and Sediment Yields in the Middle 1015 Fork Salmon River, Idaho. (Thesis) Boise State University, Boise, Idaho. 1016

Rittenour, T.M., Pearce, H.R., 2011. Dune activity in the Idaho Falls Dune field on the 1017 Snake River Plain, southeastern Idaho. Geological Society of America Abstracts 1018 with Programs 43, 7.

Romme, W., Allen, C.D., Bailey, J.D., Baker, W.L., Bestelmeyer, B.T., Brown, P.M., 1020 Eisenhart, K.S., Floyd, L., Huffman, D.W., Jacobs, B.F., Miller, R.F., Muldavin, E.H., 1021 Swetnam, T.W., Tausch, R.J., Weisberg, P.J., 2009. Historical and modern distur- 1022 bance regimes, stand structures, and landscape dynamics in piñon-juniper vegeta- 1023 tion of the western United States. Rangeland Ecology \& Management 62, 203-222. 1024

Shinker, J.J., 2010. Visualizing spatial heterogeneity of western US climate variability. 1025 Earth Interactions 14, 1-15.

Shinneman, D.J., Baker, W.L., 2009. Historical fire and multidecadal drought as context 1027 for PJ woodland restoration in western Colorado. Ecological Applications 19, 1028 $1231-1245$.

Shuman, B., Henderson, A., Coleman, S.N., Stone, J.R., Fritz, S.C., Stevens, L.R., Power, 1030 M.J., Whitlock, C., 2009. Holocene lake-level trends in the Rocky Mountains, 1031 U.S.A. Quaternary Science Reviews $28,1961-1979$.

\author{
1032
}

Skakesby, R.A., Doerr, S.H., 2006. Wildfire as a hydrological and geomorphological 1033 agent. Earth-Science Reviews 74, 269-307.

Smith, F.A., Betancourt, J.L., 2003. The effects of Holocene temperature fluctuations on 1035 the evolution and ecology of Neotoma (woodrats) in Idaho and northwestern Utah. 1036 Quaternary Research 59, 160-171.

Stahle, D., Fye, F., Cook, E., Griffin, R., 2007. Tree-ring reconstructed megadroughts over 1038 North America since A.D. 1300. Climatic Change 83, 133-149. 1039

Stuiver, M., Reimer, P.J., 1993. Extended ${ }^{14} \mathrm{C}$ database and revised CALIB Radiocarbon 1040 Calibration Program. Radiocarbon 35, 215-230. 104

Surovell, T.A., Finley, J.B., Smith, G.M., Brantingham, P.J., Kelly, R., 2009. Correcting tem- 1042 poral frequency distributions for taphonomic bias. Journal of Archaeological Sci- 1043 ence 36, 1715-1724.

Svenson, L.O., 2010. Fire and Climate in a Lodgepole Forest of Central Idaho: Annual, 1045 Decadal, Centennial and Millennial Perspectives. (Thesis) Boise State University, 1046 Boise, Idaho.

Trouet, V., Taylor, A.H., Wahl, E.R., Skinner, C.N., Stephens, S.L., 2010. Fire-climate inter- 1048 actions in the American West since 1400 CE. Geophysical Research Letters. http:// 1049 dx.doi.org/10.1029/2009GL041695/.

Unbanhowar Jr., C.E., 2004. Interaction of fire, climate and vegetation change at a 1051 large landscape scale in the Big Woods of Minnesota, USA. The Holocene 14, 1052 661-676.

USDA, Natural Resources Conservation Service, United States Department of the 1054 Interior, National Park Service, 2011. Soil survey of City of Rocks National Reserve, 1055 Idaho.

Veblen, T.T., Baker, W.L., Montenegro, G., Swetnam, T.W. (Eds.), 2003. Fire and Climatic 1057 Change in Temperate Ecosystems of the Western Americas. Springer, Series, Eco- 1058 logical Studies, 160, p. 446.

Webb, R.H., Betancourt, J.L., 1990. The spatial distribution of radiocarbon ages from 1060 packrat middens. In: Betancourt, J.L., Van Devender, T.R., Martin, P.S. (Eds.), Packrat 1061 Middens: The Last 40,000 Years of Biotic Change: Tucson. University of Arizona 1062 Press, Arizona, pp. 85-102.

Weppner, K.N., 2012. Climate Drivers and Landscape Response: Holocene Fire, Vegeta- 1064 tion, and Erosion at City Of Rocks National Reserve, Idaho. (Thesis) Boise State Uni- 1065 versity, Boise, Idaho.

Westerling, A.L., Brown, T.J., Gershunov, A., Cayan, D.R., Dettinger, M.D., 2003. Climate 1067 and wildfire in the western United States. Bulletin of the American Meteorological 1068 Society 84 (5), 595-604.

Westerling, A.L., Hidalgo, H.G., Cayan, D.R., Swetnam, T.W., 2006. Warming and earlier 1070 spring increase western U.S. forest wildfire activity. Science 313, 940-943. 1071

Westerling, A.L., Turner, E.A., Smithwick, A.H., Romme, W.H., Ryan, M.G., 2011. Con- 1072 tinued warming could transform Greater Yellowstone fire regimes by mid-21st 1073 century. PNAS: Proceedings of the National Academy of Sciences 108, 1074 13165-13170.

Western Regional Climate Center, d. http://www.wrcc@dri.edu.

Whitlock, C. Dean, W.E, Fritz, S.C. Stevens, LR., Stone, J.R, Power, M.J., Rosenbaum, 1077 J.R., Pierce, K.L., Bracht-Flyr, B.B., 2012. Holocene seasonal variability inferred 1078 
This is an author-produced, peer-reviewed version of this article. The final, definitive version of this document can be found online at Quaternary Research,

published by Elsevier. Copyright restrictions may apply. DOI: 10.1016/j.yqres.2013.06.004.

K.N. Weppner et al. / Quaternary Research $x x x$ (2013) $x x x-x x x$

1079 from multiple proxy records from Crevice Lake, Yellowstone National Park, USA.

1081

1082

1083

Q22 1084 Palaeogeography, Palaeoclimatology, Palaeoecology 331-332, 90-103.

Wilcox, B.P., Turnbull, L., Young, M.H., Williams, C.J., Ravi, S., Seyfried, M.S., Bowling, D.R., Scott, R.L., Germino, M.J., Caldwell, T.G., Wainwright, J., 2011. Invasion of shrublands by exotic grasses: ecohydrological consequences in cold versus warm deserts. Ecohydrology.
Wise, E.K., 2010. Spatiotemporal variability of the precipitation dipole transition zone 1085 in the western United States. Geophysical Research Letters 37, LO7706. http:// 1086 dx.doi.org/10.1029/2009GL042193.

Zdanowicz, C.M., Zielinski, G.A., Germani, M.S., 1999. Mount Mazama eruption: 1088 calendrical age verified and atmospheric impact assessed. Geology 27, 1089 621-624. 